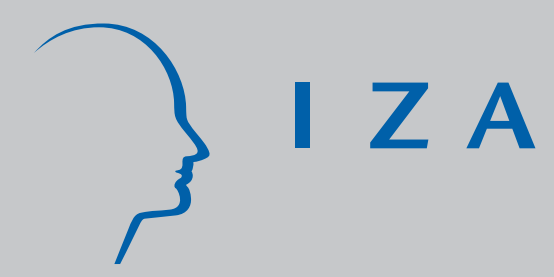

IZA DP No. 2494

Life Satisfaction and Economic Outcomes in Germany

Pre- and Post-Unification

Richard A. Easterlin

Anke C. Zimmermann

December 2006 


\title{
Life Satisfaction and Economic Outcomes in Germany Pre- and Post-Unification
}

\author{
Richard A. Easterlin \\ University of Southern California \\ and IZA Bonn \\ Anke C. Zimmermann \\ University of Southern California
}

Discussion Paper No. 2494

December 2006

\author{
IZA \\ P.O. Box 7240 \\ 53072 Bonn \\ Germany \\ Phone: +49-228-3894-0 \\ Fax: +49-228-3894-180 \\ E-mail: iza@iza.org
}

\begin{abstract}
Any opinions expressed here are those of the author(s) and not those of the institute. Research disseminated by IZA may include views on policy, but the institute itself takes no institutional policy positions.

The Institute for the Study of Labor (IZA) in Bonn is a local and virtual international research center and a place of communication between science, politics and business. IZA is an independent nonprofit company supported by Deutsche Post World Net. The center is associated with the University of Bonn and offers a stimulating research environment through its research networks, research support, and visitors and doctoral programs. IZA engages in (i) original and internationally competitive research in all fields of labor economics, (ii) development of policy concepts, and (iii) dissemination of research results and concepts to the interested public.
\end{abstract}

IZA Discussion Papers often represent preliminary work and are circulated to encourage discussion. Citation of such a paper should account for its provisional character. A revised version may be available directly from the author. 
IZA Discussion Paper No. 2494

December 2006

\section{ABSTRACT \\ Life Satisfaction and Economic Outcomes in Germany Pre- and Post-Unification ${ }^{*}$}

Throughout Germany real income has trended upward since 1991, but life satisfaction has risen in the East, fallen in the West, and been fairly stable for Germany as a whole. By 1997 the initial excess of West over East Germany was cut by over one-half; since then, the differential has changed very little, and even edged slightly upward. The post-unification decline in West Germany appears to be a break with the pattern in the seven years prior to unification and occurs among Germans, European foreigners, and Turkish foreigners. After 1997, Turkish foreigners, unlike the others, continue to decline in life satisfaction, and by 2004, their initial excess over East Germans largely disappears. The life satisfaction of postunification migrants from East Germany to the West is somewhat less than that of Germans and European foreigners in the West, but higher than that of Turkish foreigners and of Germans in East Germany. Migrants from the West to East Germany have life satisfaction about equal to that of Germans in that region. Trends and differences in overall life satisfaction are most systematically related to reports on satisfaction with income, next to the unemployment rate, and least of all, to absolute real income.

JEL Classification: D60, I31, D1, O52

Keywords: $\quad$ subjective well-being, domain satisfaction, German unification

Corresponding author:

Anke C. Zimmermann

Department of Economics

University of Southern California

Los Angeles, CA 90089-0253

USA

E-mail: azimmerm@usc.edu

\footnotetext{
* Easterlin is grateful for the opportunity to spend a week at ZUMA (Centre for Survey Research and Methodology, Mannheim, Germany) as a visiting scholar in October 2005, and Zimmermann, for the opportunity to participate in a SOEP seminar at Cornell University in September 2005. The paper has benefited greatly from comments by Heinz-Herbert Noll and Stefan Weick. The University of Southern California provided financial support.
} 


\section{Introduction}

How satisfied with their lives are the people of Germany, and how does satisfaction differ between East and West? How has life satisfaction changed since unification? How does the life satisfaction of foreigners compare with that of Germans, and among foreigners, the Turks with Europeans? What of Germans who moved between the two regions since unification - how have they fared? What has been chiefly responsible for determining the levels and changes in life satisfaction? These are the concerns of this article - population differentials, trends, and sources of change in life satisfaction in Germany, pre- and post-unification.

Until the last few decades, well-being has typically been inferred from what are known as “objective” measures - GDP per capita, life expectancy, educational attainment, and the like. Recently, however, increasing attention has been paid to measures of "subjective” well-being (SWB) - responses to questions on personal happiness or overall life satisfaction. A substantial methodological literature discusses the reliability, validity, and comparability of the responses to such questions (Clark et al., 2006; DiTella and MacCulloch, 2006; Frey and Stutzer, 2002ab; Graham, forthcoming; Kahneman et al.,1999; Layard 2005; Veenhoven 1993). The consensus is that SWB measures, though not without their shortcomings, are meaningful measures of well-being.

Our focus here is overall satisfaction with life, the answer on a 0 to 10 integer scale to the following question: "How satisfied are you with your life, all things considered?” We examine the course of life satisfaction over time in West and East Germany and Germany as a whole, and its trends and differences among subgroups of the population. Of special interest is the status of foreigners, a growing proportion of the 
population. One projection to 2050, for example, puts the non-German segment of the population at close to one-quarter, of which over three-fourths would be non-Western (Coleman, 2006, p. 414).

We also investigate how trends and differences in life satisfaction are related to economic outcomes. Non-economic factors influence life satisfaction too, but our initial analysis of the data revealed that in Germany since 1991 life satisfaction has been most systematically related to economic outcomes, while the influence of non-economic factors has been much more idiosyncratic. Hence, we focus our attention on the effect of economic outcomes.

Very little has been written on this subject. One exception is an econometric study by Frijters et al. (2004a) of life satisfaction in East Germany 1991-2001 that uses the same data source as the present study (cf. also Frijters et al., 2004b). The main conclusion of their analysis is evident from the title: Money Does Matter! Evidence from Increasing Real Income and Life Satisfaction in East Germany following Reunification.

By comparison, our study looks at West as well as East Germany, at Germany as a whole, and various subgroups of the population within West and East Germany, and adds three more years of experience. As will be seen, this more comprehensive approach yields quite different results. Although economic outcomes do matter for life satisfaction, real income alone - the focus of the analysis of Frijters et al. - is not a very good explanatory variable. The unemployment rate does better than real income. Coupling income with the unemployment rate yields no improvement over the unemployment rate alone. However, a single subjective variable, satisfaction with income, is usually as good or better in explaining life satisfaction than the unemployment rate or the two objective 
variables together. The positive association of life satisfaction and satisfaction with income found here is by no means inevitable; for example, over the life cycle subjective well-being in the United States and financial satisfaction move in almost diametrically opposed ways (Easterlin 2006).

\section{Data, Population Groups, Measures, and Methodology}

The data are those of the Socio-Economic Panel (SOEP), conducted annually since 1984 in West Germany and since 1991 in East Germany, weighted so as to be representative of the population generally of each region (Haisken-DeNew and Frick, 2005). ${ }^{1}$ The population of each region is subdivided into Germans and foreigners, and the foreign population of West Germany, into Turkish and European foreigners. In addition, migrants between the two regions since 1990 - almost all of them Germans - are examined separately. ${ }^{2}$

The relative numbers of the population groups is indicated in Table 1, col. 1. As can be seen, in East Germany the number of both internal migrants from West Germany and foreigners is very small relative to that of Germans.

There are both similarities and differences among the population groups. The gender and age compositions of the total populations of East and West Germany are much alike (Table 1, Panel A, cols. 2-4). But the two regions differ markedly in ethnic composition. Foreigners in Germany are concentrated almost wholly in the West, averaging in the period under study about one-twelfth of the population there (cols. 5-8).

\footnotetext{
1 The data used in this publication were made available to us by the German Socio-Economic Panel Study at the German Institute for Economic Research (DIW), Berlin.

2 The SOEP includes a measure that indicates in which region the respondent lived in 1989. Respondents are identified as migrants if they reside in the other part of Germany during the year of the survey.
} 
In contrast, in East Germany foreigners comprise less than one percent of the total. In both East and West, foreigners and internal migrants, when compared with Germans in those regions, typically have the gender and age characteristics of populations of migrant origin - disproportionately male and concentrated in the younger working ages (cols. 24).

Germans in West Germany are better educated than those in the East, and more highly concentrated in white collar occupations and self-employment (Table 2, cols. 1, 58). Within West Germany foreigners and internal migrants are less educated than resident Germans and correspondingly less employed in white collar and self-employed work. The Turkish population, which has the lowest education level of all, is highly concentrated in semi-skilled and unskilled occupations. The younger age composition of those of migrant origin is reflected in a considerably lower proportion of them being pensioners (Table 2, col. 4).

The picture within East Germany is different from that within the West. Migrants from the West are better educated than resident East Germans and almost four out of five are in white collar jobs or self-employed, compared with less than three out of five for resident East Germans. The very small foreign population, most of them of East European origin, have the highest education of all and are three-fourths white collar. This group differs markedly from others, however, in having an extremely high unemployment rate - on the order of one in three (col. 3).

The analysis here is based on the annual means of life satisfaction and economic outcomes for each region and population group (the basic data are given in Appendix A). We focus principally on three measures of economic outcomes. Two are quite commonly 
used - household income and the unemployment rate. We created a measure of the unemployment rate (proportion of respondents in the labor force who are not currently employed) for each population group from the SOEP data, because official unemployment rates from the Federal Statistical Office Germany are only available for the regional aggregates. The correlation between our measure and the official measures for East and West Germany as a whole from 1991 to 2004, is respectively 0.77 and 0.92 . (For the regional aggregates we also investigate briefly another measure of economic outcomes, the inflation rate, reported below in the analysis of trends over time.)

Our third principal measure of economic outcomes, satisfaction with income, is less commonly used. This is the response to the question: "How satisfied are you with your household income?” Responses are on an integer scale from 0 up to 10.

The measure of satisfaction with income derives from the domain approach to analyzing life satisfaction, pioneered by psychologist Angus Campbell and his collaborators $(1976,1981)$. In this approach, overall satisfaction with life is seen as being influenced by satisfaction in different domains of life - finances, family life, health, work, and so on. Satisfaction in each domain is, in turn, viewed as reflecting the extent to which objective outcomes in that domain match the respondent's goals or needs in that realm, and satisfaction may vary with changes in objective conditions, goals, or both. In this framework, satisfaction with income can be thought of as an intermediary variable between objective conditions and overall life satisfaction. Satisfaction with income is affected, on the one hand, by objective circumstances, such as income and unemployment, and, on the other, by subjective perceptions of material needs. Hence, in including in this analysis satisfaction with income as our third measure of economic 
outcomes, we are implicitly bringing into play a factor other than actual income and unemployment, namely, perceptions of material needs.

This is a descriptive analysis, aimed at establishing the broad facts with regard to trends and differences, and relationships among the various measures. Hence we rely throughout on tables and time series graphs of the summary measures, checking our impressions against ordinary least squares regressions. As will be seen, the patterns and relationships are usually quite evident from the tables and graphs.

In exploring the relation of life satisfaction to satisfaction with income a question arises about a possible common bias in the two measures. Responses on satisfaction whether with life in general or household income - are known to be influenced by individual personality. Consider two persons with identical perceived needs, income, and unemployment experience. If one of them is neurotic and the other not, it is likely that this person's responses on satisfaction with life in general and satisfaction with household income will both be lower than the other's, because a neurotic tends to assess his or her circumstances more negatively (Diener and Lucas, 1999). A correlation of life satisfaction with actual income or unemployment for the two individuals would show no relation, because objective circumstances are the same. But a correlation of life satisfaction with satisfaction with income would show a perfect positive correlation, and lead to the erroneous inference that income satisfaction was the source of the difference between the two in life satisfaction, whereas, in fact, the cause is a personality difference that has similarly affected the responses on both life satisfaction and satisfaction with income. 
The present analysis should be largely free of the influence of this personality effect, however, because we study averages over time and among population groups, not point-of-time differences among individuals. Personality tends to be a stable individual characteristic and hence would not explain changes over time in satisfaction responses. If, for example, we were to find both average life satisfaction and satisfaction with income of the above two individuals - one neurotic and one not - declining over time (a positive time series correlation), personality could not be the explanation of the positive correlation because so far as personality is concerned, satisfaction with both life and income, like personality, should be the same from one time to the next. Similarly, a comparison of two population groups (say Germans and foreigners) at a point in time with regard to life satisfaction and satisfaction with income should be free of the effect of personality bias, unless it can be demonstrated that the two groups differ systematically with regard to personality characteristics known to affect subjective responses.

In what follows we take up first average differences among the various population groups over the entire period for which data are available. We then turn to examining changes over time. In each section, we first describe the life satisfaction patterns, and then take up their relations to the economic outcome variables.

\section{Results}

\section{Cross Sectional Differences within Germany}

Life satisfaction - Over the period 1991-2004, life satisfaction in West Germany has been, on average, considerably higher than in the East, the difference amounting, on a scale of 0 to 10 , to about 0.7 points (Table 3, panel A-1, column 1). Within West 
Germany Germans rank highest, followed in order by European foreigners (over seventenths of whom are from Southern Europe), migrants from East Germany, and Turkish foreigners (panel A-2). The range from high to low for these four groups equals 0.4 points. For the period since 1984, the same order and range prevails, except that migrants from the East drop out because of lack of data (panel B).

Within East Germany the German population is highest, as in the West, followed closely by migrants from West Germany (panel A-2). The tiny group of European foreigners in East Germany average considerably lower in life satisfaction than any other population group, and about one point less than East Germans. All of the West German population groups, including the lowest group within West Germany, Turkish foreigners, average higher in life satisfaction over the period 1991-2004 than any of the East German groups.

Relation to economic outcomes. - Differences among population groups in life satisfaction generally correspond fairly closely to differences in economic outcomes. Compared with the East, West Germany as a whole has higher income, less unemployment, and higher satisfaction with income (Table 3, Panel A-1, cols. 2-4). Within West Germany, the rank order from best to worst of the four population subgroups is the same for each of the economic outcome variables as for life satisfaction, both in 1991-2004 and 1984-2004 (Panels A-2, B). If Germans in East Germany are added to this ranking they tend to follow the general pattern. They are lower in life satisfaction than the lowest West German group, the Turkish population, and about as low or lower on economic outcomes. 
The data for foreigners in East Germany must be viewed with some caution, because they are based on only 146 observations for the entire period. Even so, foreigners in East Germany tend to correspond reasonably well to the general pattern of positive association between life satisfaction and economic outcomes. They are the worst of the total of seven population groups in West and East Germany in terms of life satisfaction, unemployment, and satisfaction with income. However, their absolute level of income is somewhat out of line, placing them fifth out of the seven groups. The expected favorable impact of income on life satisfaction for this group is no doubt countered by their extremely high unemployment rate, which, if the data can be credited, is more than two times greater than that of any other population group.

The most notable exception to the high correlation evident in the table between levels of life satisfaction and economic outcomes is for migrants to East Germany from the West. Although they are next to last of the seven population groups in the ordering by life satisfaction, they rank third in income and fourth in both unemployment and satisfaction with income. It may be that the migrants from the West bring with them higher perceptions of material needs than those that prevail among East Germans, and this higher material standard offsets the effect of their higher income, yielding satisfaction with income and life in general not much different from those of East Germans. The difference between life satisfaction at origin and destination for internal migrants - a research issue of considerable interest in itself - is a subject for another paper. For studies of these migration flows around the time of unification, see Burda 1993 and Grabka et al. 1999. 
Statistically, the economic outcome variables that are most systematically related to differences in life satisfaction among the seven population groups are satisfaction with income and unemployment; each of these, considered singly, accounts for the same proportion of variance in life satisfaction, 81 per cent (Appendix B). In contrast, household income by itself has no statistically significant explanatory power, due, no doubt, to the anomalous income ranking of internal migrants and foreigners in East Germany.

\section{Trends over time}

Life satisfaction. - In West Germany the trend in life satisfaction from unification through 1997 is downward, and in East Germany, upward, with a consequent narrowing of the differential between the two from an initial value of 1.3 points to about 0.6 points (Figure 1). Since then the trends have been fairly horizontal, with the differential edging up slightly after 2000.

For Germany as a whole, the net outcome of the contrasting trends of life satisfaction in East and West is a mild downtrend through about 1997, followed by a leveling off. As is clear from the figure, the trend for Germany is fairly close to that for West Germany. This is hardly surprising because West Germany makes up almost threefourths of the total population.

In West Germany the downtrend of life satisfaction after 1991 was common to all four population groups in that region (Figure 2). But while life satisfaction for most population groups leveled off after 1997, that of Turkish foreigners continued to worsen. Compared with Germans in West Germany, the shortfall of Turkish foreigners in life 
satisfaction increased between the first and second halves of the period, while the shortfalls of European foreigners and migrants from the East declined slightly (Table 4). Moreover, with East Germans improving between the first and second halves of the period, the excess of life satisfaction of the West German Turkish population over East Germans has come close to disappearing.

Generalizations about trends prior to unification are handicapped by the fact that the data relate only to West Germany, are for a fairly short period, seven years, and fluctuate considerably. Read in conjunction with the post-unification patterns however, one's impression is that up to 1991 none of the three population groups trends very much up or down, while after 1991, noticeable declines set in.

In East Germany, where Germans account for over 99 percent of the population, the uptrend for Germans is, not surprisingly, virtually identical with that for East Germany as a whole (Figure 3). Life satisfaction for the small number of migrants from the West fluctuates around that of Germans with little clear evidence of a trend. For the even smaller number of foreigners there is a sharp uptrend, and the initial shortfall of this group relative to Germans largely disappears. By 2004 life satisfaction differences among the three population groups in East Germany are quite small.

Relation to economic outcomes. - Trends in life satisfaction for the various population groups correspond chiefly to movements in satisfaction with income and the unemployment rate, with income satisfaction typically providing a somewhat better statistical explanation of life satisfaction. Household income, whether considered singly or together with the unemployment rate, has little consistent relation to life satisfaction, 
and more often than not, the relationship, such as it is, is negative, not positive as one would expect.

For Germany as a whole, the parallel between the trend in life satisfaction and the trends in both satisfaction with income and the unemployment rate is quickly apparent from a simple graph (Figure 4, upper panel); a similar graph of life satisfaction and household income gives little evidence of any relationship (lower panel). (A trend adjustment to household income would not be appropriate here, because increasing real income is typically expected to generate a corresponding increase in life satisfaction.)

The relationship of life satisfaction to economic outcomes in West Germany postunification is much like that for Germany as a whole - considerable similarity between the time series pattern of life satisfaction and those of the unemployment rate and income satisfaction (Figure 5, upper panel), and little similarity to that of absolute real income (lower panel). For the short pre-unification period, patterns of association are less apparent. In the few years before unification there is an upsurge in each of the economic outcome variables much like that in overall life satisfaction, but prior to that systematic relationships between economic outcomes and life satisfaction are not particularly evident.

In East Germany the pattern of overall life satisfaction appears to follow most closely that in satisfaction with income - both show a rise and fall, although the amplitude of the movement is greater for satisfaction with income (Figure 6, upper panel). The pattern for household income is more like that for life satisfaction than was true in West Germany, rising along with life satisfaction, but then income levels off 
rather than declining as life satisfaction does. In East Germany there is little evidence of a relationship between the unemployment rate and life satisfaction.

These visual impressions can be checked against statistical regressions of life satisfaction on each of the three economic outcome variables. Taking the main regional aggregates together - Germany, West Germany, and East Germany - one finds satisfaction with income most related statistically to life satisfaction - the proportion of variance explained ranges from somewhat under one-half to three-quarters (Table 5, lines 1-3; for complete regression results see Appendix C). The unemployment rate does as well as income satisfaction in Germany and West Germany, but fails in East Germany. Household income performs least well - never accounting for more than 30 per cent of the variance in life satisfaction, and in one of the two cases where this is so, the relation of life satisfaction to real income is negative rather than positive (see Appendix C).

In principle, the inflation rate is a macro-economic variable that might be expected to affect life satisfaction negatively. Unlike the unemployment rate, it is not possible with our data to construct a measure of the inflation rate specific to each population group. But time series of the inflation rate as measured by the consumer price index, can be computed for Germany as a whole, 1991-2004, West Germany, 1985-2002, and East Germany, 1992-2002 (Federal Statistical Office, Germany, available at www.destatis.de). For each of these geographical aggregates and periods, we regressed life satisfaction on the inflation rate alone and in various combinations with household income and the unemployment rate. Considered singly, the inflation rate is unrelated to life satisfaction in Germany as a whole, 1991-2004, and in West Germany, 1985-2002; positively related in West Germany, 1991-2002, and negatively related in East Germany, 
1992-2002. In multiple regressions with household income and the unemployment rate, the inflation rate is never statistically significant. In general, for those population groups for which data are available the inflation rate adds little or nothing to the analysis.

The findings on life satisfaction in relation to the different economic outcome variables are very largely replicated when one examines the population subgroups. Rather than present separate graphs, we summarize the regression results for the other groups in the remainder of Table 5 (lines 4-8), omitting Germans in both East and West Germany, because they largely duplicate the overall results for these regions. As is clear from the table, satisfaction with income continues to provide the best statistical explanation of life satisfaction, and its performance is even better relative to the other economic outcome variables than was the case for the regional aggregates in lines 1-3.

\section{Summary and Discussion}

The experience of most countries for which data are available is that rising real income is not accompanied by increasing subjective well-being (Easterlin 1974, 1995, 2005). Germany as a whole since unification fits this pattern. But within Germany there are noteworthy differences in the trends of various population groups. The initial shortfall in life satisfaction of East relative to West Germany diminished noticeably to about 1997; subsequently it leveled off and then in the first few years of this century edged slightly upward.

Within West Germany, life satisfaction among Germans, European foreigners, and Turkish foreigners fell after unification. Although trends in the short seven-year preunification period are hard to establish, the post-unification declines appear to be a break 
with pre-unification patterns of stability for these groups. The life satisfaction of postunification migrants from East Germany to the West is somewhat less than that of Germans and European foreigners there, but higher than that of the Turkish population. Since 1997, life satisfaction in West Germany has been fairly stable among Germans, European foreigners and internal migrants from East Germany, but that of Turkish foreigners has continued to decline. By 2004 the initially higher life satisfaction of the West German Turkish population compared with East Germans had virtually disappeared. Within East Germany, there has been convergence in life satisfaction between Germans and the quite small groups of internal migrants from the West and European foreigners.

Economic conditions appear to have played an important part in the differences in the levels and trends of the various population groups. However, it is not so much the objective state of these conditions, measured here by real income and the unemployment rate, as people's subjective evaluation of these conditions, as reflected in their reports on satisfaction with income. In general, income satisfaction is much more consistently related to differences among and trends within population groups than the two objective measures. Considering all three measures together - satisfaction with income, unemployment, and income - real income is least associated statistically with trends and differences in life satisfaction.

The importance here of the association between subjective evaluations of economic conditions and life satisfaction is of significance for the study of subjective well-being generally. In the current literature on the economics of happiness the typical approach is to estimate regression equations of life satisfaction in relation to a variety of 
objective measures - income, employment status, marital status, health, and so on (Blanchflower and Oswald, 2004; Frey and Stutzer, 2002ab). An alternative is to look at life satisfaction in relation to people's perceptions of these conditions, the "life domain" approach. To date, very little work has been done by economists using this approach (but see Easterlin, 2006; Easterlin and Sawangfa, 2006; Rojas, forthcoming; van Praag et al., 2003; van Praag and Ferrer-i-Carbonell, 2004, chapters 3 and 4). The life domain approach does not preclude the analysis of objective life circumstances, but it forces the analyst to think of the effect of these circumstances in relation to what people want out of life - their income norms, family life aspirations, health goals, and so forth. The analysis here is obviously only a first step toward this more comprehensive inquiry, but the results are suggestive of the promise of the life domain approach in the study of subjective wellbeing. 


\section{References}

Blanchflower, D. G., Oswald, A., 2004. Well-being over time in Britain and the USA. Journal of Public Economics 88, 1359-1386.

Burda, M.C., 1993. The determinants of East-West German migration. European Economic Review 37, 452-461.

Campbell, A., 1981. The Sense of Well-Being in America. New York, McGraw-Hill.

Campbell, A., Converse, P.E., Rodgers, W.L., 1976. The Quality of American Life. New York, Russell Sage Foundation.

Clark, A.E., Frijters, P., Shields, M.A., 2006. Income and happiness: evidence, explanations and economic implications, unpublished paper, 8th August.

Coleman, D., 2006. Immigration and ethnic change in low-fertility countries: a third demographic transition, Population and Development Review 32, 401-446.

Diener, E., Lucas, R. E., 1999. Personality and subjective well-being. In: Kahneman, D., Diener, E., Schwarz, N. (Eds.). Well-Being: The Foundations of Hedonic Psychology, New York, Russell Sage, pp. 213-229.

DiTella, R., MacCulloch, R., 2006. Some uses of happiness data in economics. Journal of Economic Perspectives 20, 25-46.

Easterlin, R.A., 1974. Does economic growth improve the human lot? In: David, P. A., Reder, M. W. (Eds.). Nations and Households in Economic Growth: Essays in Honor of Moses Abramovitz, New York, Academic Press, Inc.

Easterlin, R.A., 1995. Will raising the incomes of all increase the happiness of all? Journal of Economic Behavior and Organization 27, 1-34. 
Easterlin, R.A., 2005. Feeding the illusion of growth and happiness: A reply to Hagerty and Veenhoven. Social Indicators Research 74, 429 - 443

Easterlin, R.A., 2006. Life cycle happiness and its sources: intersections of psychology, economics and demography. Journal of Economic Psychology 27, 463-482.

Easterlin, R.A., Sawangfa O., 2006. Happiness and domain satisfaction: theory and evidence. Unpublished manuscript.

Frey, B.S., Stutzer, A., 2002a. Happiness and Economics. Princeton, Princeton University Press.

Frey, B.S., Stutzer, A., 2002b. What can economists learn from happiness research? Journal of Economic Literature XL, 402-435.

Frijters P., Haisken-DeNew, J.P., Shields, M.A., 2004a. Money does matter! Evidence from increasing real income and life satisfaction in East Germany following reunification. The American Economic Review 94, 730-740.

Frijters, P., Shields, M.A., Haisken-DeNew, J.P., 2004b. Investigating the patterns and determinants of life satisfaction in Germany following reunification. Journal of Human Resources 39, 649-74.

Grabka, M.M., Schwarze, J., Wagner, G.G., 1999. How unification and immigration affected the German income distribution. European Economic Review 43, 867-878.

Graham, C., forthcoming. The economics of happiness. In: Durlauf, S., Blume, L. (Eds.). The New Palgrave Dictionary of Economics. 2nd Edition. Palgrave-MacMillan. Haisken-DeNew, J.P., Frick, J.R. (Eds.), 2005. Desktop companion to the German SocioEconomic Panel (SOEP). Version 8.0. Berlin, DIW (German Institute for Economic Research). 
Kahneman, D., Diener, E., Schwarz, N. (Eds.). Well-Being: The Foundations of Hedonic Psychology. New York, Russell Sage.

Layard, R., 2005. Happiness, Lessons from a New Science. New York, The Penguin Press.

Rojas, M., forthcoming. The complexity of well-being: a life satisfaction conception and domains-of-life approach. In: Gough, I., McGregor, A. (Eds.). Researching WellBeing in Developing Countries. New York, Cambridge University Press.

Van Praag, B.M.S., Ferrer-i-Carbonell, A., 2004. Happiness Quantified: A Satisfaction Calculus Approach. Oxford, Oxford University Press, chapter 3.

Van Praag, B.M.S., Frijters P., Ferrer-i-Carbonell, A., 2003. The anatomy of subjective well-being. Journal of Economic Behavior and Organization 51, 29-49.

Veenhoven, R., 1993. Happiness in Nations: Subjective Appreciation of Life in 56 Nations 1946-1992. RISBO, Studies in Sociale en Culturele Verandering, Nr. 2, Erasmus University Rotterdam. 


\section{Table 1}

\section{Population by Demographic Characteristics All Germany, 1991-2004, and West Germany, 1984-2004}

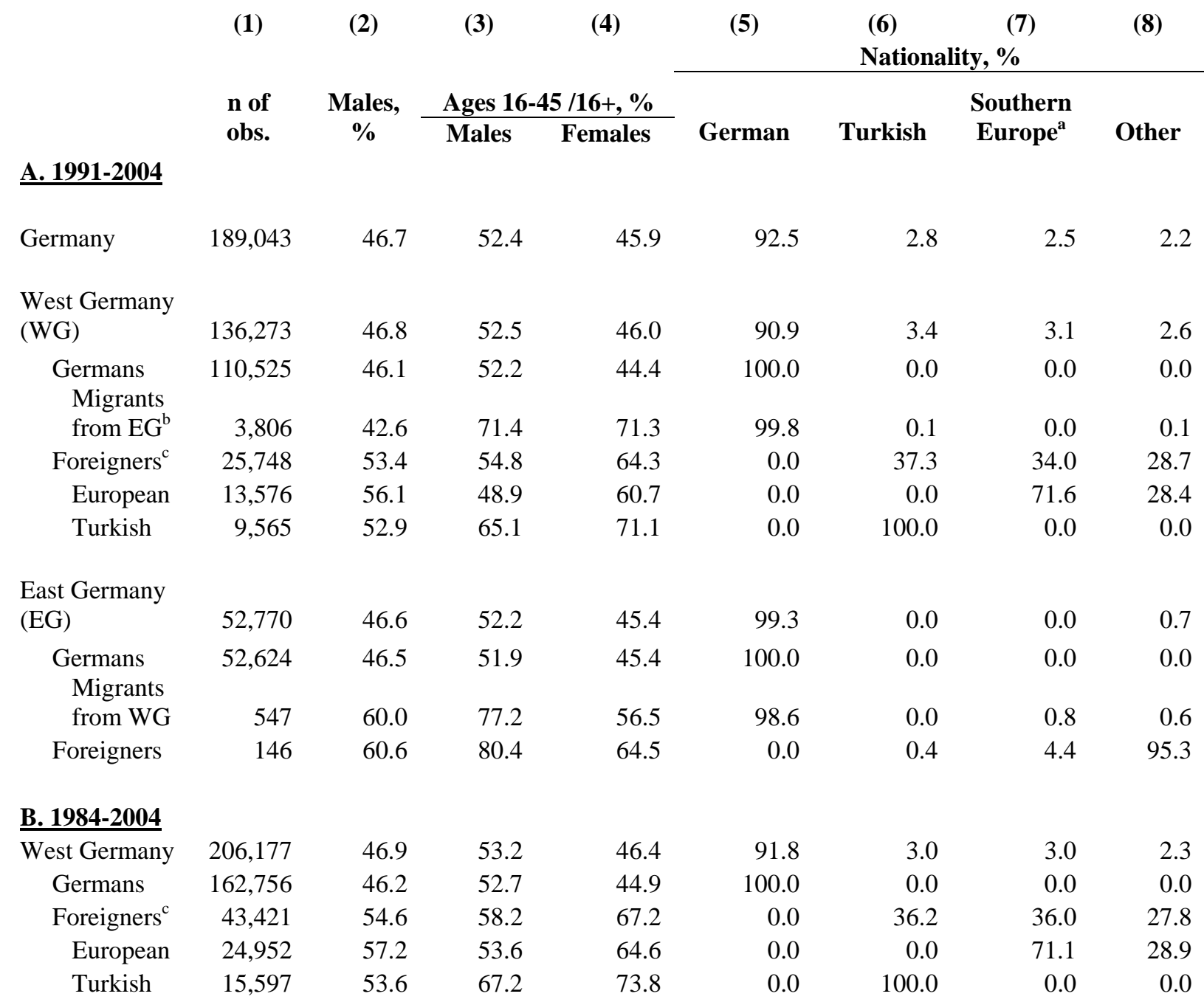

a. Italy, former Yugoslavia, Greece, and Spain.

b. Includes a very small number of migrants in 1990 .

c. Includes foreigners other than European or Turkish, numbering about 7 percent of all foreigners in West Germany. 


\section{Table 2}

\section{Population by Socio-Economic Characteristics All Germany, 1991-2004, and West Germany, 1984-2004}

\begin{tabular}{|c|c|c|c|c|c|c|c|c|c|}
\hline & \multirow[t]{2}{*}{ (1) } & (2) & (3) & (4) & (5) & (6) & (7) & (8) & \multirow{2}{*}{$\begin{array}{c}(9) \\
\text { House- }\end{array}$} \\
\hline & & \multirow{2}{*}{\multicolumn{3}{|c|}{$\begin{array}{l}\text { Work status }{ }^{\mathrm{a},} \\
\% \text { of pop. } 16-95\end{array}$}} & \multicolumn{4}{|c|}{ Occupation $^{\mathrm{b}}, \%$ of employed } & \\
\hline & \multirow{2}{*}{$\begin{array}{c}\text { Educa- } \\
\text { tion }> \\
\text { secon- } \\
\text { dary, \% }\end{array}$} & & & & & & Blue & ollar & hold \\
\hline & & $\begin{array}{l}\text { Em- } \\
\text { ploye } \\
\text { d }\end{array}$ & $\begin{array}{l}\text { Unem- } \\
\text { ployed }\end{array}$ & $\begin{array}{l}\text { Pen- } \\
\text { sioner }\end{array}$ & $\begin{array}{l}\text { White } \\
\text { collar }\end{array}$ & $\begin{array}{l}\text { Self- } \\
\text { empl. }\end{array}$ & Skilled & $\begin{array}{l}\text { Semi- } \\
\text { and un- } \\
\text { skilled }\end{array}$ & $\begin{array}{c}\text { income, } \\
1995 \\
\text { euros }\end{array}$ \\
\hline \multicolumn{10}{|l|}{ A. $1991-2004^{\mathrm{a}}$} \\
\hline Germany & 16.8 & 54.0 & 6.2 & 25.2 & 52.4 & 9.9 & 17.4 & 21.3 & 26,764 \\
\hline $\begin{array}{l}\text { West Germany } \\
\text { (WG) }\end{array}$ & 17.8 & 54.5 & 4.8 & 24.7 & 53.5 & 10.1 & 15.3 & 22.0 & 28,166 \\
\hline $\begin{array}{l}\text { Germans } \\
\text { Migrants }\end{array}$ & 18.3 & 54.2 & 4.3 & 26.3 & 56.5 & 10.7 & 15.1 & 18.7 & 28,370 \\
\hline from $\mathrm{EG}^{\mathrm{b}}$ & 12.3 & 70.9 & 8.6 & 11.1 & 46.0 & 4.9 & 22.5 & 27.2 & 25,707 \\
\hline Foreigners $^{c}$ & 12.2 & 57.8 & 9.4 & 9.1 & 25.6 & 5.4 & 17.4 & 52.3 & 26,130 \\
\hline European & 12.9 & 65.7 & 7.5 & 10.0 & 28.2 & 6.7 & 18.1 & 48.1 & 28,200 \\
\hline Turkish & 6.1 & 50.3 & 12.2 & 6.4 & 14.1 & 3.6 & 19.4 & 63.1 & 24,412 \\
\hline \multicolumn{10}{|l|}{ East Germany } \\
\hline $\begin{array}{l}\text { Germans } \\
\text { Migrants }\end{array}$ & 12.4 & 51.7 & 12.0 & 27.4 & 47.0 & 8.7 & 26.7 & 18.5 & 22,505 \\
\hline from WG & 25.9 & 58.2 & 9.6 & 18.3 & 53.3 & 25.0 & 6.9 & 15.2 & 27,068 \\
\hline Foreigners & 38.8 & 47.7 & 35.5 & 11.6 & 74.8 & 3.4 & 10.0 & 12.1 & 25,079 \\
\hline \multicolumn{10}{|l|}{ B. 1984-2004 } \\
\hline West Germany & 16.2 & 54.4 & 4.3 & 23.9 & 51.3 & 10.3 & 16.3 & 23.1 & 27,466 \\
\hline Germans & 16.7 & 53.9 & 3.9 & 25.3 & 54.1 & 10.8 & 16.0 & 20.1 & 27,601 \\
\hline Foreigners $^{c}$ & 11.0 & 59.6 & 8.8 & 8.0 & 23.3 & 5.4 & 18.8 & 53.1 & 25,715 \\
\hline European & 11.6 & 67.4 & 7.0 & 8.2 & 25.8 & 6.9 & 20.1 & 48.2 & 27,290 \\
\hline Turkish & 5.4 & 52.9 & 11.4 & 5.2 & 11.7 & 3.2 & 19.3 & 65.9 & 24,485 \\
\hline
\end{tabular}

a. Work status categories not shown: not employed; in education, military or community service; do not know, no answer.

b. White collar: professional (highly qualified, and qualified), white collar worker (trained and untrained), managerial, civil service. Self-employed: self-employed (free lance), help in family business. Blue collar skilled: trained worker, foreman, farmer. Blue collar, semi-and unskilled: semi-trained worker, untrained worker, apprentice.

c. Includes foreigners other than European or Turkish, numbering about 7 percent of all foreigners in West Germany. 


\section{Table 3}

Life Satisfaction and Economic Outcomes

Mean Values, Germany by Population Subgroup, 1991 - 2004 and West Germany, $1984-2004$

(1)

\begin{tabular}{cc} 
& \multicolumn{2}{c}{ Eco } \\
\cline { 2 - 2 } Life & $\begin{array}{c}\text { Household } \\
\text { income, }^{\text {in }}\end{array}$ \\
satisfaction & 1995 euros
\end{tabular}

A. 1991 - 2004

\section{Population aggregates}

Germany

West Germany (WG)

East Germany (EG) satisfaction

6.89
7.03
6.30

6.89

6.30
(2)

Economic outcomes
(4) 


\section{Table 4}

Shortfall of Life Satisfaction of Specified Population Group Relative to Germans in West Germany, 1991 - 1997 and 1998 - 2004

European foreigners Migrants from East Germany Turkish foreigners

$\begin{array}{cc}1991-\mathbf{1 9 9 7} & \mathbf{1 9 9 8}-\mathbf{2 0 0 4} \\ 0.08 & 0.02 \\ 0.20 & 0.17 \\ 0.33 & 0.48\end{array}$

Source: Tables A-4 to A-7. 


\section{Table 5}

Adjusted $\mathbf{R}^{2}$ from Time Series Regression of Life Satisfaction on Specified Variable, by Population Group, Specified Period

\begin{tabular}{|c|c|c|c|c|c|}
\hline Line & $\begin{array}{l}\text { Population } \\
\text { group }\end{array}$ & Period & $\begin{array}{c}\text { Satisfaction } \\
\text { with Income }\end{array}$ & $\begin{array}{c}\text { Unemployment } \\
\text { Rate }\end{array}$ & $\begin{array}{c}\text { Household } \\
\text { Income, } \\
1995 \text { euros }\end{array}$ \\
\hline 1. & Germany & $1991-2004$ & $0.62 * * *$ & $0.49 * *$ & $0.15^{\mathrm{a}}$ \\
\hline $2 a$. & West Germany & 1991-2004 & $0.76^{* * *}$ & $0.67 * * *$ & -0.05 \\
\hline $2 b$. & West Germany & $1984-2004$ & $0.43^{* * *}$ & $0.57^{* * *}$ & $0.29 * *^{\mathrm{b}}$ \\
\hline 3. & East Germany & 1991-2004 & $0.75^{* * *}$ & 0.15 & $0.30^{*^{\mathrm{a}}}$ \\
\hline 4a. & $\begin{array}{l}\text { European } \\
\text { foreigners (WG) }\end{array}$ & 1991-2004 & $0.46^{* *}$ & 0.11 & -0.08 \\
\hline $\begin{array}{l}4 \mathrm{~b} . \\
5 \mathrm{a} .\end{array}$ & $\begin{array}{l}\text { European } \\
\text { foreigners (WG) } \\
\text { Turkish }\end{array}$ & 1984-2004 & $0.38 * *$ & 0.10 & -0.02 \\
\hline $5 b$. & $\begin{array}{l}\text { foreigners (WG) } \\
\text { Turkish }\end{array}$ & 1991-2004 & $0.61^{* * *}$ & $0.49 * *$ & 0.07 \\
\hline & foreigners (WG) & 1984-2004 & $0.71^{* * *}$ & $0.61^{* * *}$ & 0.08 \\
\hline 6. & $\begin{array}{l}\text { Migrants to WG } \\
\text { from EG }\end{array}$ & $1992-2004$ & 0.02 & 0.12 & 0.00 \\
\hline 7. & Foreigners (EG) & 1991-2004 & $0.39 *$ & -0.06 & $0.25^{*^{\mathrm{a}, \mathrm{b}}}$ \\
\hline 8. & $\begin{array}{l}\text { Migrants to EG } \\
\text { from WG }\end{array}$ & 1993-2004 & $0.31 *$ & -0.07 & -0.02 \\
\hline
\end{tabular}

Source: Appendix C
a. $1992-2004$
b. Regression coefficient of life satisfaction on income is negative

$$
\begin{aligned}
& \text { *** Prob }>\mathrm{F}<0.001 \\
& * * \text { Prob }>\mathrm{F}=0.001 \text { to }<0.01 \\
& \text { * Prob }>\mathrm{F}=0.01 \text { to } 0.05
\end{aligned}
$$




\section{Fig 1}

Life Satisfaction in East, West, and All of Germany, 1991-2004

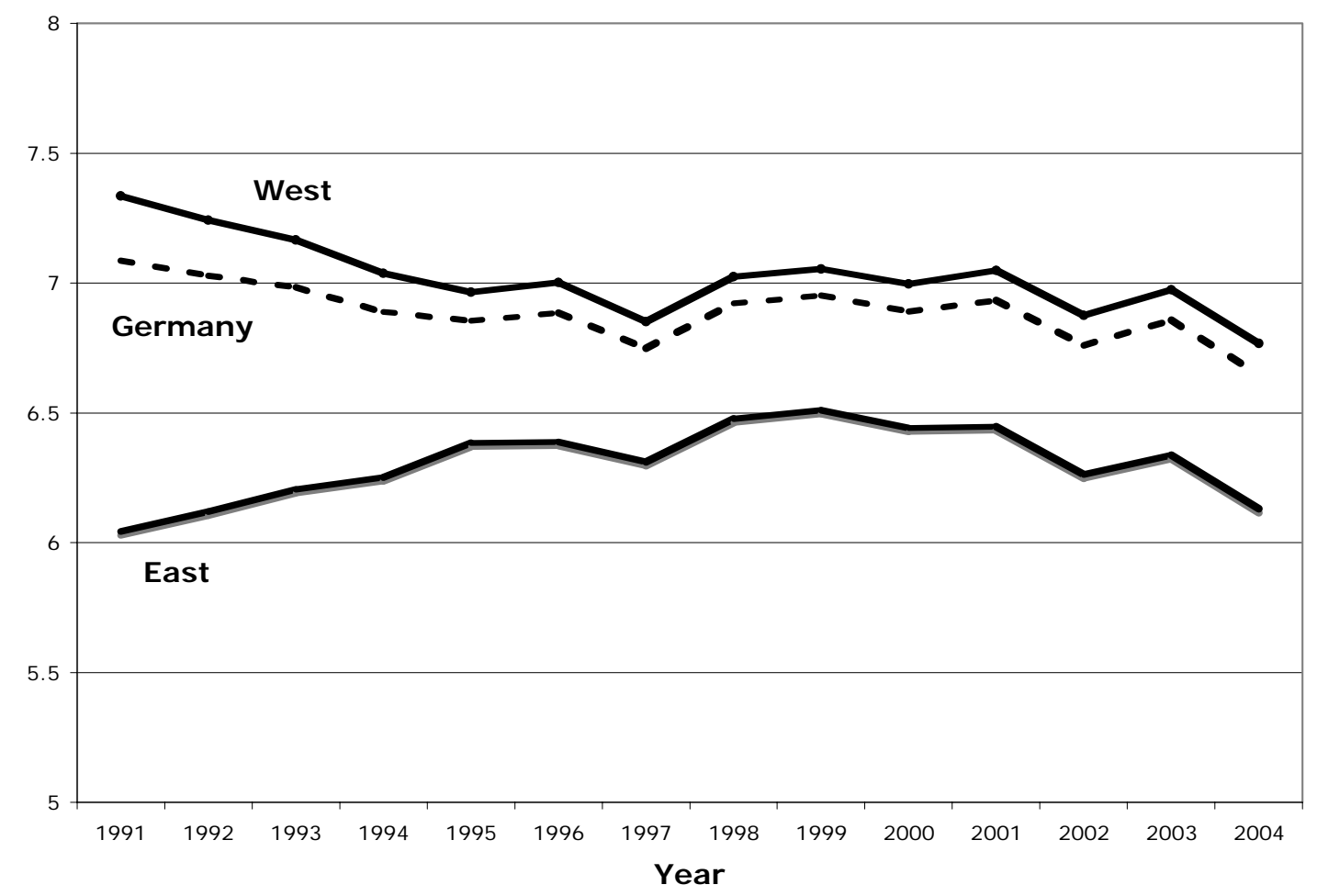

Source: Appendix Tables A-1, A-2, A-3. 


\section{Fig 2}

Life Satisfaction of Population Subgroups, West Germany, 1984-2004

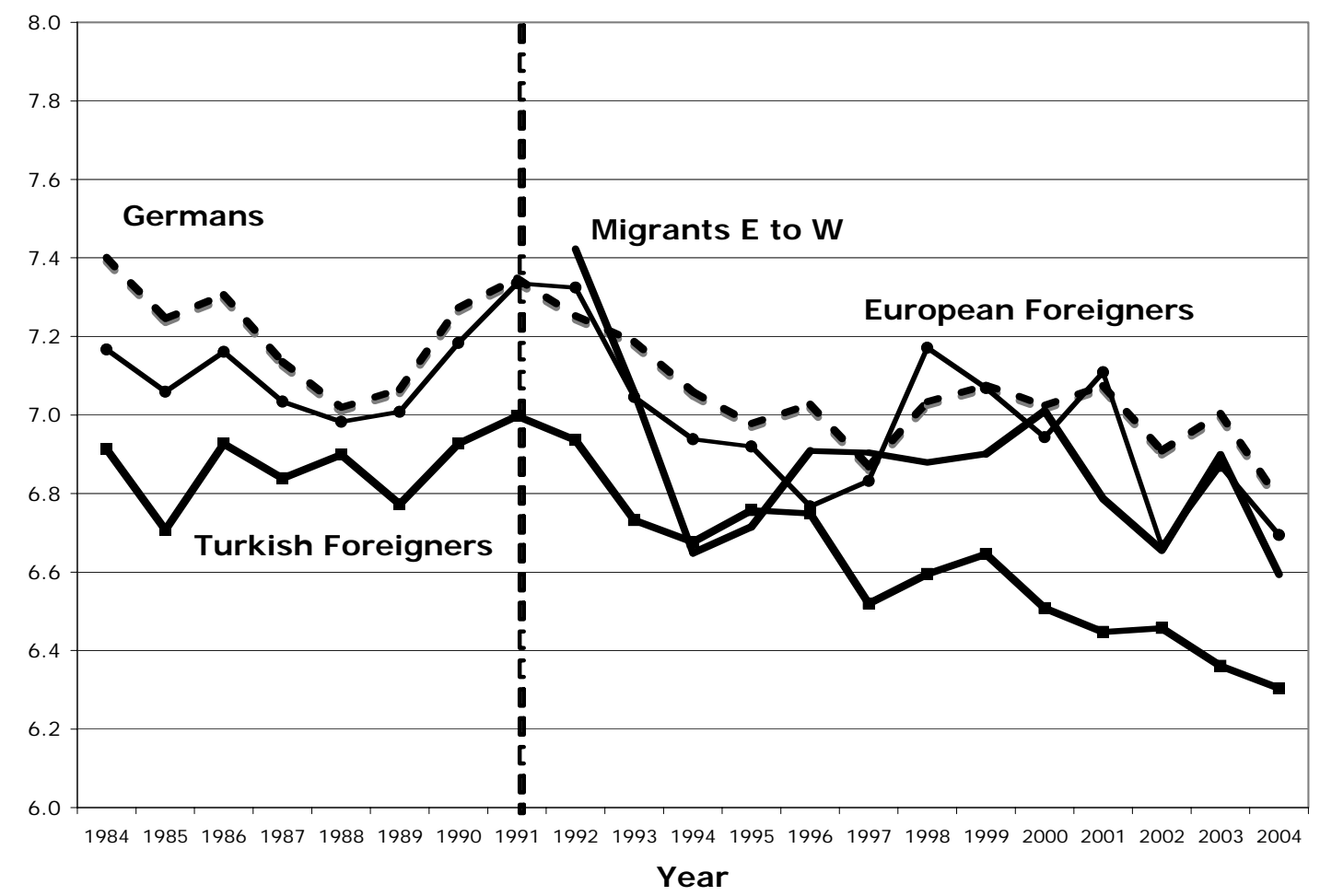

Source: Appendix Tables A-4, A-5, A-6, A-7. 


\section{Fig 3}

Life Satisfaction of Population Subgroups, East Germany, 1991-2004

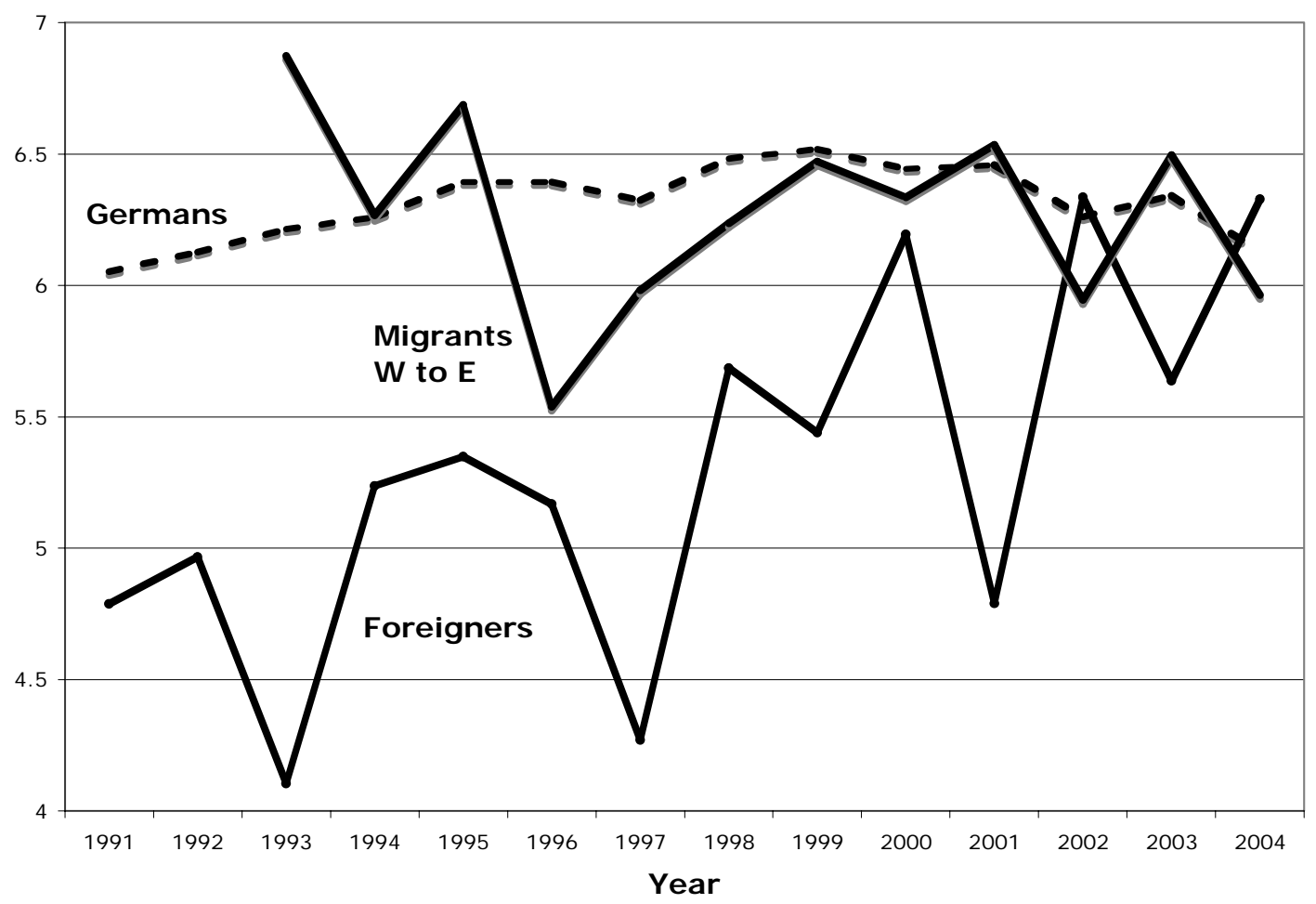

Source: Appendix Tables A-8, A-9, A-10. 


\section{Fig 4}

Life Satisfaction, Unemployment, Satisfaction with Income, and Household Income Germany, 1991-2004
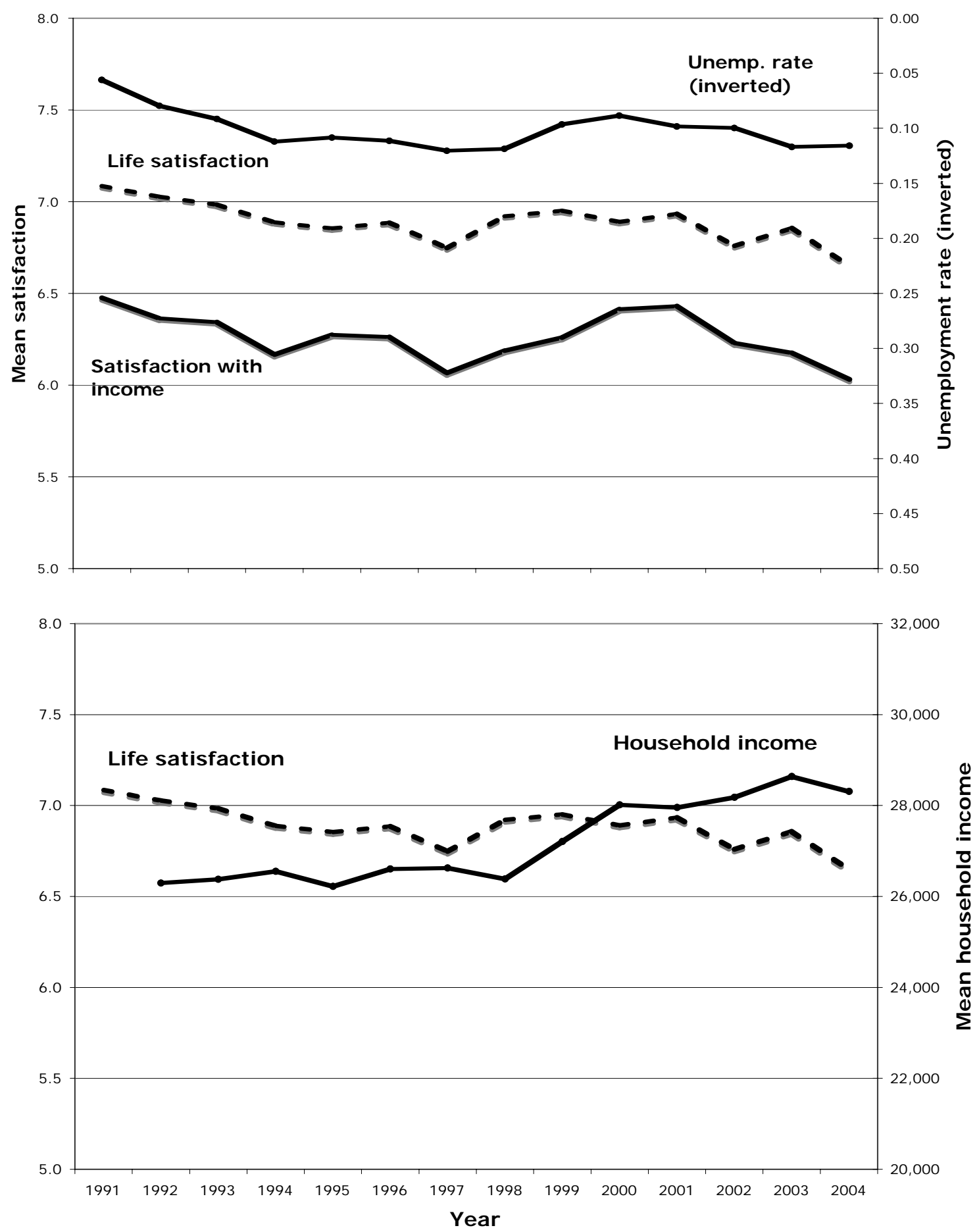

Source: Appendix Table A-1. 


\section{Fig 5}

Life Satisfaction, Unemployment, Satisfaction with Income, and Household Income West Germany, 1984-2004
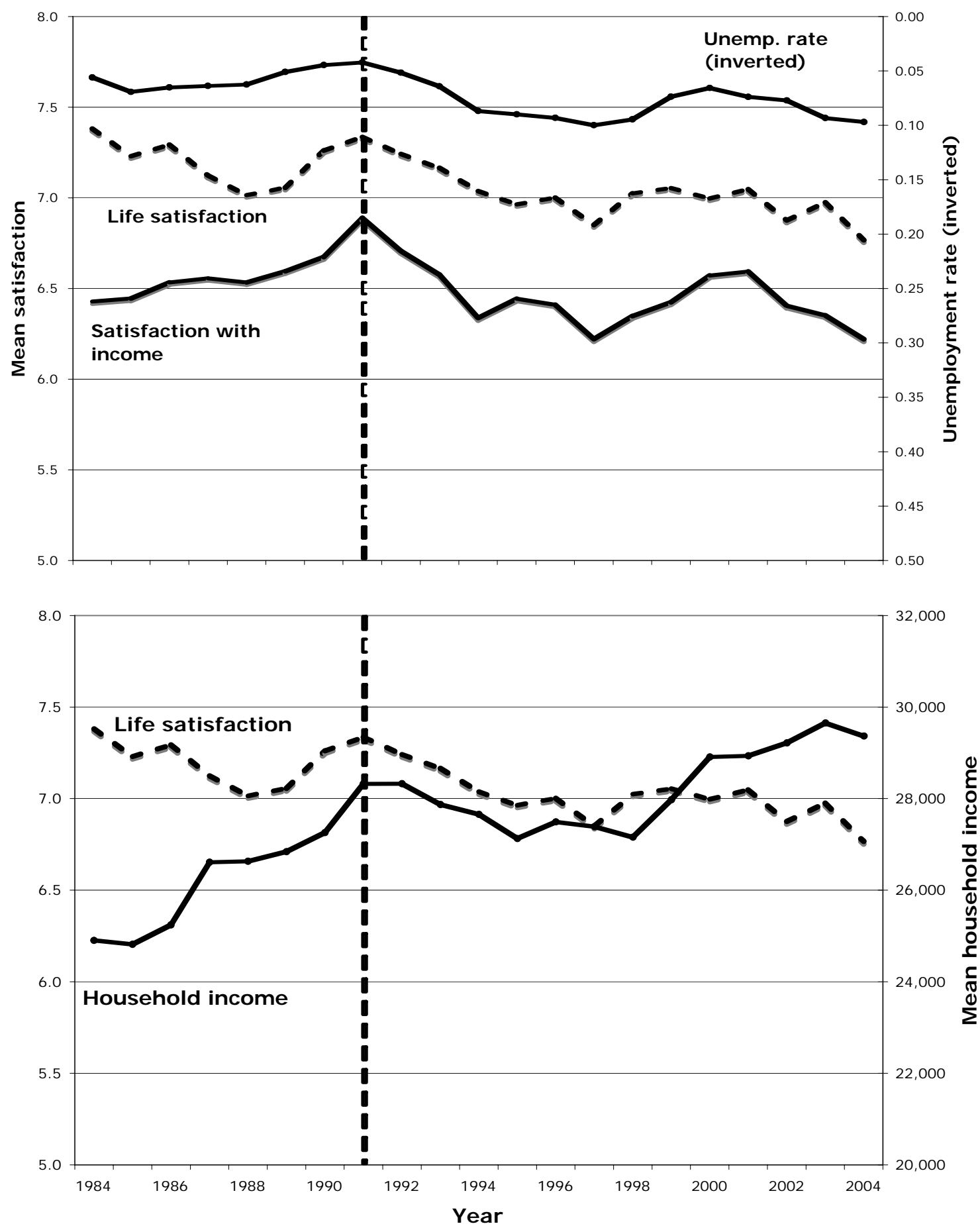

Source: Appendix Table A-2. 


\section{Fig 6}

Life Satisfaction, Unemployment, Satisfaction with Income, and Household Income East Germany, 1991-2004
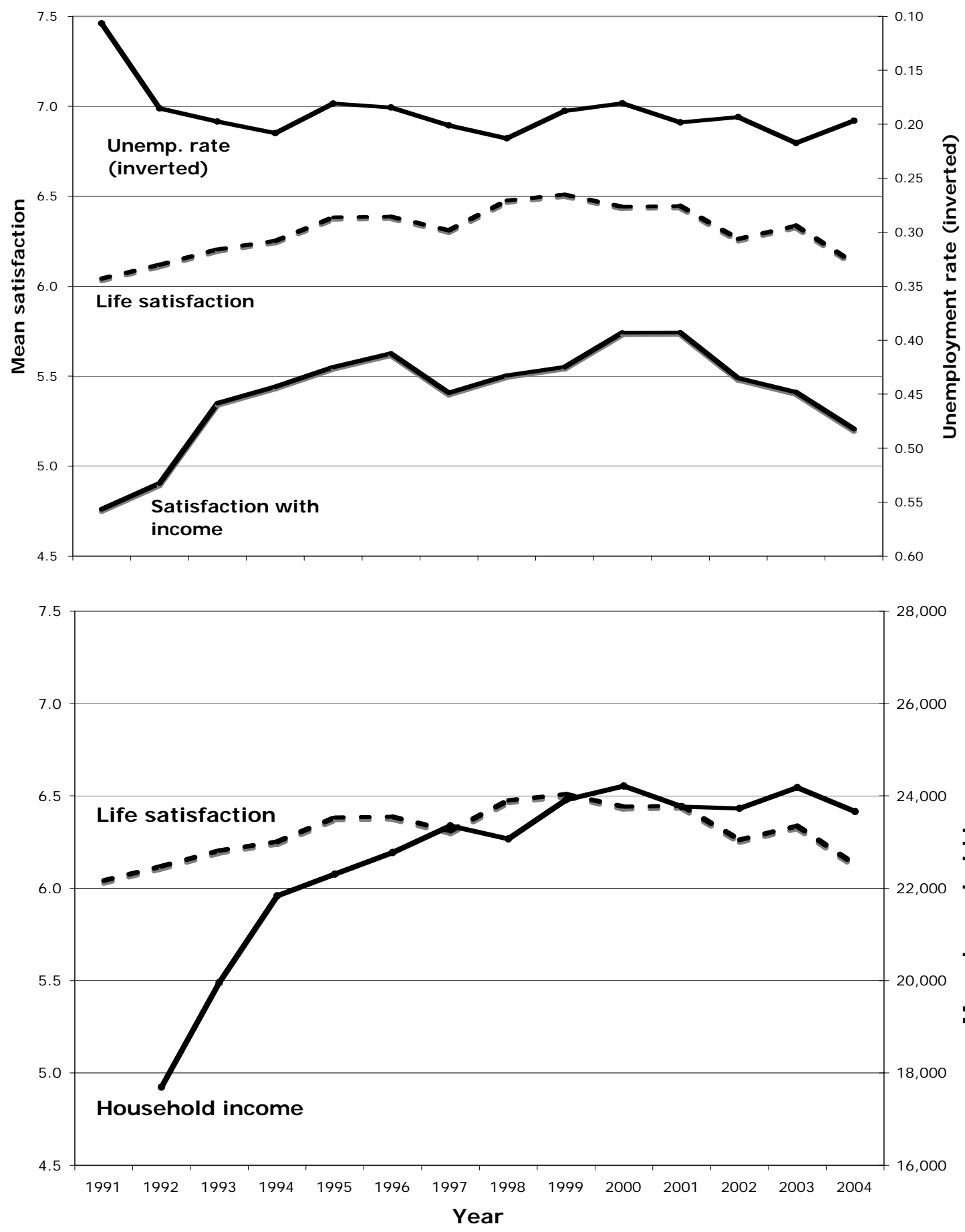

Source: Appendix Table A-3. 


\section{Appendix A: Basic Data}

Table A-1

All Germany 1991-2004

\begin{tabular}{|l|c|c|c|c|c|c|c|r|}
\hline Year & LS & n LS & $\begin{array}{c}\text { Sat } \\
\text { hhinc }\end{array}$ & $\begin{array}{c}\mathbf{n} \\
\text { sat_inc }\end{array}$ & $\begin{array}{c}\text { HH } \\
\text { Income }\end{array}$ & n inc & $\begin{array}{c}\text { unemp } \\
\text { rate }\end{array}$ & $\begin{array}{c}\text { n unemp. } \\
\text { rate }\end{array}$ \\
\hline $\mathbf{1 9 9 1}$ & 7.08 & 12,812 & 6.48 & 12,811 & ${ }^{a} 28,322$ & ${ }^{a} 8,985$ & 0.0561 & 12,941 \\
\hline $\mathbf{1 9 9 2}$ & 7.03 & 12,592 & 6.36 & 12,551 & 26,295 & 12,676 & 0.0795 & 12,676 \\
\hline $\mathbf{1 9 9 3}$ & 6.98 & 12,413 & 6.34 & 12,146 & 26,375 & 12,475 & 0.0915 & 12,475 \\
\hline $\mathbf{1 9 9 4}$ & 6.89 & 12,178 & 6.17 & 11,950 & 26,549 & 12,246 & 0.1120 & 12,246 \\
\hline $\mathbf{1 9 9 5}$ & 6.85 & 12,589 & 6.27 & 12,359 & 26,219 & 12,650 & 0.1084 & 12,650 \\
\hline $\mathbf{1 9 9 6}$ & 6.89 & 12,384 & 6.26 & 12,154 & 26,603 & 12,405 & 0.1114 & 12,405 \\
\hline $\mathbf{1 9 9 7}$ & 6.75 & 12,175 & 6.07 & 11,913 & 26,623 & 12,198 & 0.1204 & 12,198 \\
\hline $\mathbf{1 9 9 8}$ & 6.92 & 13,509 & 6.19 & 13,207 & 26,382 & 13,543 & 0.1187 & 13,543 \\
\hline $\mathbf{1 9 9 9}$ & 6.95 & 13,026 & 6.26 & 12,757 & 27,206 & 13,055 & 0.0964 & 13,055 \\
\hline $\mathbf{2 0 0 0}$ & 6.89 & 12,666 & 6.41 & 12,438 & 28,013 & 12,701 & 0.0885 & 12,701 \\
\hline $\mathbf{2 0 0 1}$ & 6.93 & 12,264 & 6.43 & 12,097 & 27,952 & 12,293 & 0.0983 & 12,293 \\
\hline $\mathbf{2 0 0 2}$ & 6.76 & 11,849 & 6.23 & 11,648 & 28,177 & 11,877 & 0.0996 & 11,877 \\
\hline $\mathbf{2 0 0 3}$ & 6.86 & 19,201 & 6.18 & 18,917 & 28,632 & 19,236 & 0.1168 & 19,236 \\
\hline $\mathbf{2 0 0 4}$ & 6.65 & 18,695 & 6.03 & 18,313 & 28,305 & 18,747 & 0.1158 & 18,747 \\
\hline mean & & & & & & & & \\
$\mathbf{9 1 - 0 4}$ & 6.89 & 188,353 & 6.25 & 185,261 & ${ }^{b} 26,764$ & 176,102 & 0.1017 & 189,043 \\
\hline $\begin{array}{l}\text { mean } \\
\mathbf{9 1 - 9 7}\end{array}$ & 6.92 & 87,143 & 6.28 & 85,884 & 25,941 & 74,650 & 0.0973 & 87,591 \\
\hline $\begin{array}{l}\text { mean } \\
\mathbf{9 8 - 0 4}\end{array}$ & 6.85 & 101,210 & 6.22 & 99,377 & 27,756 & 101,452 & 0.1071 & 101,452 \\
\hline
\end{tabular}

a. West German data. No estimates available for East Germany 1984 - 1990.

b. 1991 for West Germany only. 
Table A-2

West Germany 1984-2004

\begin{tabular}{|l|c|r|r|r|r|r|r|r|}
\hline Year & LS & n LS & $\begin{array}{c}\text { Sat } \\
\text { hhinc }\end{array}$ & $\begin{array}{c}\text { n } \\
\text { sat_inc }\end{array}$ & $\begin{array}{c}\text { HH } \\
\text { Income }\end{array}$ & \multicolumn{1}{c|}{ n inc } & $\begin{array}{c}\text { unemp } \\
\text { rate }\end{array}$ & $\begin{array}{c}\text { n unemp. } \\
\text { rate }\end{array}$ \\
\hline $\mathbf{1 9 8 4}$ & 7.38 & 11,557 & 6.43 & 11,417 & 24,902 & 11,610 & 0.0561 & 11,610 \\
\hline $\mathbf{1 9 8 5}$ & 7.23 & 10,463 & 6.44 & 10,300 & 24,817 & 10,503 & 0.0693 & 10,503 \\
\hline $\mathbf{1 9 8 6}$ & 7.29 & 10,067 & 6.53 & 9,969 & 25,240 & 10,101 & 0.0652 & 10,101 \\
\hline $\mathbf{1 9 8 7}$ & 7.12 & 9,936 & 6.56 & 9,861 & 26,609 & 9,970 & 0.0638 & 9,970 \\
\hline $\mathbf{1 9 8 8}$ & 7.02 & 9,469 & 6.53 & 9,397 & 26,634 & 9,509 & 0.0625 & 9,509 \\
\hline $\mathbf{1 9 8 9}$ & 7.06 & 9,165 & 6.60 & 9,091 & 26,839 & 9,195 & 0.0510 & 9,195 \\
\hline $\mathbf{1 9 9 0}$ & 7.26 & 8,978 & 6.67 & 8,932 & 27,257 & 9,016 & 0.0446 & 9,016 \\
\hline $\mathbf{1 9 9 1}$ & 7.34 & 8,902 & 6.89 & 8,892 & 28,322 & 8,985 & 0.0423 & 8,985 \\
\hline $\mathbf{1 9 9 2}$ & 7.24 & 8,822 & 6.71 & 8,796 & 28,326 & 8,875 & 0.0516 & 8,875 \\
\hline $\mathbf{1 9 9 3}$ & 7.17 & 8,786 & 6.58 & 8,589 & 27,872 & 8,824 & 0.0641 & 8,824 \\
\hline $\mathbf{1 9 9 4}$ & 7.04 & 8,590 & 6.34 & 8,429 & 27,656 & 8,643 & 0.0868 & 8,643 \\
\hline $\mathbf{1 9 9 5}$ & 6.96 & 9,070 & 6.44 & 8,914 & 27,129 & 9,118 & 0.0899 & 9,118 \\
\hline $\mathbf{1 9 9 6}$ & 7.00 & 8,873 & 6.41 & 8,714 & 27,491 & 8,891 & 0.0932 & 8,891 \\
\hline $\mathbf{1 9 9 7}$ & 6.85 & 8,713 & 6.22 & 8,541 & 27,389 & 8,730 & 0.1000 & 8,730 \\
\hline $\mathbf{1 9 9 8}$ & 7.02 & 9,833 & 6.35 & 9,632 & 27,158 & 9,857 & 0.0946 & 9,857 \\
\hline $\mathbf{1 9 9 9}$ & 7.05 & 9,408 & 6.43 & 9,232 & 27,974 & 9,433 & 0.0738 & 9,433 \\
\hline $\mathbf{2 0 0 0}$ & 7.00 & 9,094 & 6.57 & 8,952 & 28,909 & 9,120 & 0.0657 & 9,120 \\
\hline $\mathbf{2 0 0 1}$ & 7.05 & 8,834 & 6.59 & 8,717 & 28,936 & 8,857 & 0.0739 & 8,857 \\
\hline $\mathbf{2 0 0 2}$ & 6.88 & 8,540 & 6.40 & 8,402 & 29,217 & 8,562 & 0.0771 & 8,562 \\
\hline $\mathbf{2 0 0 3}$ & 6.97 & 14,352 & 6.35 & 14,149 & 29,653 & 14,382 & 0.0933 & 14,382 \\
\hline $\mathbf{2 0 0 4}$ & 6.77 & 13,958 & 6.22 & 13,673 & 29,367 & 13,996 & 0.0970 & 13,996 \\
\hline $\mathbf{m e a n}$ & & & & & & & & \\
$\mathbf{8 4 - 0 4}$ & 7.08 & 205,410 & 6.49 & 202,599 & 27,446 & 206,177 & 0.0726 & 206,177 \\
\hline $\mathbf{m e a n}$ & & & & & & & & \\
$\mathbf{8 4 - 9 0}$ & 7.19 & 69,635 & 6.54 & 68,967 & 26,054 & 69,904 & 0.0588 & 69,904 \\
\hline $\mathbf{m e a n}$ & & & & & & & & \\
$\mathbf{9 1 - 0 4}$ & 7.03 & 135,775 & 6.46 & 133,632 & 28,166 & 136,273 & 0.0797 & 136,273 \\
\hline $\mathbf{m e a n}$ & & & & & & & & \\
$\mathbf{9 1 - 9 7}$ & 7.08 & 61,756 & 6.51 & 60,875 & 27,736 & 62,066 & 0.0757 & 62,066 \\
\hline $\mathbf{m e a n}$ & & & & & & & & 74,207 \\
$\mathbf{9 8 - 0 4}$ & 6.96 & 74,019 & 6.39 & 72,757 & 28,683 & 74,207 & 0.0846 & \\
\hline
\end{tabular}


Table A-3

East Germany 1991-2004

\begin{tabular}{|l|c|c|c|c|c|c|c|c|}
\hline Year & LS & n LS & $\begin{array}{c}\text { Sat } \\
\text { hhinc }\end{array}$ & $\begin{array}{c}\mathbf{n} \\
\text { sat_inc }\end{array}$ & $\begin{array}{c}\text { HH } \\
\text { Income }\end{array}$ & n inc & $\begin{array}{c}\text { unemp } \\
\text { rate }\end{array}$ & $\begin{array}{c}\text { n unemp. } \\
\text { rate }\end{array}$ \\
\hline $\mathbf{1 9 9 1}$ & 6.04 & 3,910 & 4.76 & 3,919 & & & 0.11 & 3,956 \\
\hline $\mathbf{1 9 9 2}$ & 6.12 & 3,770 & 4.90 & 3,755 & 17,691 & 3,801 & 0.19 & 3,801 \\
\hline $\mathbf{1 9 9 3}$ & 6.20 & 3,627 & 5.35 & 3,557 & 19,957 & 3,651 & 0.20 & 3,651 \\
\hline $\mathbf{1 9 9 4}$ & 6.25 & 3,588 & 5.44 & 3,521 & 21,834 & 3,603 & 0.21 & 3,603 \\
\hline $\mathbf{1 9 9 5}$ & 6.38 & 3,519 & 5.55 & 3,445 & 22,305 & 3,532 & 0.18 & 3,532 \\
\hline $\mathbf{1 9 9 6}$ & 6.39 & 3,511 & 5.63 & 3,440 & 22,772 & 3,514 & 0.18 & 3,514 \\
\hline $\mathbf{1 9 9 7}$ & 6.31 & 3,462 & 5.41 & 3,372 & 23,349 & 3,468 & 0.20 & 3,468 \\
\hline $\mathbf{1 9 9 8}$ & 6.48 & 3,676 & 5.50 & 3,575 & 23,069 & 3,686 & 0.21 & 3,686 \\
\hline $\mathbf{1 9 9 9}$ & 6.51 & 3,618 & 5.55 & 3,525 & 23,915 & 3,622 & 0.19 & 3,622 \\
\hline $\mathbf{2 0 0 0}$ & 6.44 & 3,572 & 5.74 & 3,486 & 24,212 & 3,581 & 0.18 & 3,581 \\
\hline $\mathbf{2 0 0 1}$ & 6.45 & 3,430 & 5.74 & 3,380 & 23,766 & 3,436 & 0.20 & 3,436 \\
\hline $\mathbf{2 0 0 2}$ & 6.26 & 3,309 & 5.49 & 3,246 & 23,731 & 3,315 & 0.19 & 3,315 \\
\hline $\mathbf{2 0 0 3}$ & 6.34 & 4,849 & 5.41 & 4,768 & 24,180 & 4,854 & 0.22 & 4,854 \\
\hline $\mathbf{2 0 0 4}$ & 6.13 & 4,737 & 5.21 & 4,640 & 23,662 & 4,751 & 0.20 & 4,751 \\
\hline mean & & & & & & & & \\
$\mathbf{9 1 - 0 4}$ & 6.30 & 52,578 & 5.38 & 51,629 & 22,522 & 48,814 & 0.19 & 52,770 \\
\hline mean & & & & & & & & \\
$\mathbf{9 1 - 9 7}$ & 6.24 & 25,387 & 5.29 & 25,009 & 21,330 & 21,569 & 0.18 & 25,525 \\
\hline mean & & & & & & & & \\
$\mathbf{9 8 - 0 4}$ & 6.37 & 27,191 & 5.49 & 26,620 & 23,764 & 27,245 & 0.20 & 27,245 \\
\hline
\end{tabular}


Table A-4

Germans, West Germany 1984-2004

\begin{tabular}{|l|c|r|r|r|r|r|r|r|}
\hline Year & LS & n LS & $\begin{array}{c}\text { Sat } \\
\text { hhinc }\end{array}$ & $\begin{array}{c}\text { n } \\
\text { sat_inc }\end{array}$ & $\begin{array}{c}\text { HH } \\
\text { Income }\end{array}$ & n inc & $\begin{array}{c}\text { unemp } \\
\text { rate }\end{array}$ & $\begin{array}{c}\text { n unemp. } \\
\text { rate }\end{array}$ \\
\hline $\mathbf{1 9 8 4}$ & 7.40 & 8,528 & 6.46 & 8,409 & 24,972 & 8,566 & 0.0509 & 8,566 \\
\hline $\mathbf{1 9 8 5}$ & 7.25 & 7,876 & 6.48 & 7,741 & 24,958 & 7,904 & 0.0648 & 7,904 \\
\hline $\mathbf{1 9 8 6}$ & 7.31 & 7,573 & 6.56 & 7,500 & 25,356 & 7,600 & 0.0615 & 7,600 \\
\hline $\mathbf{1 9 8 7}$ & 7.14 & 7,457 & 6.59 & 7,402 & 26,714 & 7,484 & 0.0591 & 7,484 \\
\hline $\mathbf{1 9 8 8}$ & 7.02 & 7,079 & 6.56 & 7,026 & 26,729 & 7,110 & 0.0600 & 7,110 \\
\hline $\mathbf{1 9 8 9}$ & 7.07 & 6,824 & 6.64 & 6,772 & 26,964 & 6,850 & 0.0496 & 6,850 \\
\hline $\mathbf{1 9 9 0}$ & 7.27 & 6,689 & 6.71 & 6,657 & 27,339 & 6,717 & 0.0415 & 6,717 \\
\hline $\mathbf{1 9 9 1}$ & 7.35 & 6,622 & 6.94 & 6,632 & 28,296 & 6,695 & 0.0390 & 6,695 \\
\hline $\mathbf{1 9 9 2}$ & 7.25 & 6,592 & 6.76 & 6,579 & 28,355 & 6,630 & 0.0463 & 6,630 \\
\hline $\mathbf{1 9 9 3}$ & 7.19 & 6,578 & 6.64 & 6,431 & 27,909 & 6,606 & 0.0586 & 6,606 \\
\hline $\mathbf{1 9 9 4}$ & 7.06 & 6,486 & 6.41 & 6,358 & 27,702 & 6,529 & 0.0818 & 6,529 \\
\hline $\mathbf{1 9 9 5}$ & 6.98 & 6,917 & 6.52 & 6,796 & 27,457 & 6,957 & 0.0775 & 6,957 \\
\hline $\mathbf{1 9 9 6}$ & 7.03 & 6,880 & 6.49 & 6,739 & 27,801 & 6,893 & 0.0825 & 6,893 \\
\hline $\mathbf{1 9 9 7}$ & 6.87 & 6,834 & 6.30 & 6,680 & 27,721 & 6,844 & 0.0912 & 6,844 \\
\hline $\mathbf{1 9 9 8}$ & 7.03 & 8,063 & 6.43 & 7,878 & 27,384 & 8,079 & 0.0878 & 8,079 \\
\hline $\mathbf{1 9 9 9}$ & 7.08 & 7,778 & 6.52 & 7,618 & 28,301 & 7,795 & 0.0649 & 7,795 \\
\hline $\mathbf{2 0 0 0}$ & 7.02 & 7,567 & 6.66 & 7,434 & 29,128 & 7,585 & 0.0607 & 7,585 \\
\hline $\mathbf{2 0 0 1}$ & 7.07 & 7,382 & 6.68 & 7,274 & 29,189 & 7,402 & 0.0661 & 7,402 \\
\hline $\mathbf{2 0 0 2}$ & 6.91 & 7,200 & 6.49 & 7,071 & 29,534 & 7,219 & 0.0710 & 7,219 \\
\hline $\mathbf{2 0 0 3}$ & 7.00 & 12,763 & 6.43 & 12,575 & 29,910 & 12,790 & 0.0877 & 12,790 \\
\hline $\mathbf{2 0 0 4}$ & 6.79 & 12,465 & 6.26 & 12,201 & 29,561 & 12,501 & 0.0915 & 12,501 \\
\hline $\mathbf{m e a n}$ & & & & & & & & \\
$\mathbf{8 4 - 0 4}$ & 7.10 & 162,153 & 6.54 & 159,773 & 27,601 & 162,756 & 0.0667 & 162,756 \\
\hline $\mathbf{m e a n}$ & & & & & & & & \\
$\mathbf{8 4 - 9 0}$ & 7.21 & 52,026 & 6.57 & 51,507 & 26,156 & 52,231 & 0.0553 & 52,231 \\
\hline $\mathbf{m e a n}$ & & & & & & & & \\
$\mathbf{9 1 - 0 4}$ & 7.05 & 110,127 & 6.53 & 108,266 & 28,370 & 110,525 & 0.0728 & 110,525 \\
\hline $\mathbf{m e a n}$ & & & & & & & & \\
$\mathbf{9 1 - 9 7}$ & 7.10 & 46,909 & 6.58 & 46,215 & 27,889 & 47,154 & 0.0683 & 47,154 \\
\hline $\mathbf{m e a n}$ & & & & & & & & 63,371 \\
$\mathbf{9 8 - 0 4}$ & 6.98 & 63,218 & 6.47 & 62,051 & 28,946 & 63,371 & 0.0781 & \\
\hline
\end{tabular}


Table A-5

\section{European Foreigners, West Germany 1984-2004}

\begin{tabular}{|c|c|c|c|c|c|c|c|c|}
\hline Year & LS & n LS & $\begin{array}{c}\text { Sat } \\
\text { hhinc }\end{array}$ & $\begin{array}{c}n \\
\text { sat_inc }\end{array}$ & $\begin{array}{c}\text { HH } \\
\text { Income }\end{array}$ & $n$ inc & $\begin{array}{c}\text { unemp } \\
\text { rate }\end{array}$ & $\begin{array}{c}\text { n unemp. } \\
\text { rate }\end{array}$ \\
\hline 1984 & 7.17 & 1,999 & 6.00 & 1,980 & 24,879 & 2,006 & 0.1023 & 2,006 \\
\hline 1985 & 7.06 & 1,722 & 5.97 & 1,698 & 23,493 & 1,730 & 0.0903 & 1,730 \\
\hline 1986 & 7.16 & 1,626 & 6.08 & 1,607 & 23,820 & 1,630 & 0.0916 & 1,630 \\
\hline 1987 & 7.03 & 1,602 & 6.11 & 1,588 & 25,571 & 1,606 & 0.0903 & 1,606 \\
\hline 1988 & 6.98 & 1,512 & 6.21 & 1,500 & 25,735 & 1,518 & 0.0655 & 1,518 \\
\hline 1989 & 7.01 & 1,445 & 6.30 & 1,429 & 25,761 & 1,447 & 0.0317 & 1,447 \\
\hline 1990 & 7.18 & 1,433 & 6.46 & 1,420 & 27,471 & 1,439 & 0.0584 & 1,439 \\
\hline 1991 & 7.34 & 1,402 & 6.56 & 1,390 & 29,196 & 1,408 & 0.0545 & 1,408 \\
\hline 1992 & 7.32 & 1,349 & 6.50 & 1,342 & 28,722 & 1,357 & 0.0735 & 1,357 \\
\hline 1993 & 7.05 & 1,349 & 6.16 & 1,311 & 29,101 & 1,353 & 0.0904 & 1,353 \\
\hline 1994 & 6.94 & 1,289 & 5.89 & 1,267 & 29,206 & 1,295 & 0.1033 & 1,295 \\
\hline 1995 & 6.92 & 1,286 & 6.13 & 1,254 & 25,946 & 1,288 & 0.1421 & 1,288 \\
\hline 1996 & 6.77 & 1,193 & 5.97 & 1,180 & 26,725 & 1,194 & 0.1598 & 1,194 \\
\hline 1997 & 6.83 & 837 & 5.67 & 829 & 26,661 & 840 & 0.1290 & 840 \\
\hline 1998 & 7.17 & 821 & 5.92 & 811 & 27,138 & 824 & 0.1078 & 824 \\
\hline 1999 & 7.07 & 722 & 5.95 & 717 & 27,350 & 725 & 0.0956 & 725 \\
\hline 2000 & 6.94 & 683 & 6.43 & 678 & 29,430 & 685 & 0.0623 & 685 \\
\hline 2001 & 7.11 & 638 & 6.37 & 636 & 29,339 & 639 & 0.0509 & 639 \\
\hline 2002 & 6.67 & 597 & 5.74 & 593 & 29,387 & 598 & 0.0493 & 598 \\
\hline 2003 & 6.87 & 706 & 5.84 & 701 & 30,378 & 707 & 0.1204 & 707 \\
\hline 2004 & 6.69 & 662 & 5.98 & 648 & 28,993 & 663 & 0.1178 & 663 \\
\hline $\begin{array}{l}\text { mean } \\
84-04 \\
\end{array}$ & 7.02 & 24,873 & 6.11 & 24,579 & 27,290 & 24,952 & 0.0940 & 24,952 \\
\hline $\begin{array}{l}\text { mean } \\
84-90 \\
\end{array}$ & 7.09 & 11,339 & 6.17 & 11,222 & 25,306 & 11,376 & 0.0752 & 11,376 \\
\hline $\begin{array}{l}\text { mean } \\
91-04 \\
\end{array}$ & 7.00 & 13,534 & 6.08 & 13,357 & 28,200 & 13,576 & 0.1026 & 13,576 \\
\hline $\begin{array}{l}\text { mean } \\
91-97 \\
\end{array}$ & 7.02 & 8,705 & 6.13 & 8,573 & 27,922 & 8,735 & 0.1086 & 8,735 \\
\hline $\begin{array}{l}\text { mean } \\
98-04\end{array}$ & 6.96 & 4,829 & 6.00 & 4,784 & 28,669 & 4,841 & 0.0923 & 4,841 \\
\hline
\end{tabular}


Table A-6

Migrants from East to West, West Germany 1992-2004

\begin{tabular}{|l|c|r|r|r|r|r|r|r|}
\hline Year & \multicolumn{1}{c|}{ LS } & \multicolumn{1}{c|}{ n LS } & $\begin{array}{c}\text { Sat } \\
\text { hhinc }\end{array}$ & $\begin{array}{c}\text { n } \\
\text { sat_inc }\end{array}$ & $\begin{array}{c}\text { HH } \\
\text { Income }\end{array}$ & n inc & $\begin{array}{c}\text { unemp } \\
\text { rate }\end{array}$ & $\begin{array}{c}\text { n unemp. } \\
\text { rate }\end{array}$ \\
\hline $\mathbf{1 9 9 2}$ & 7.42 & 95 & 6.03 & 95 & 21,339 & 95 & 0.1090 & 95 \\
\hline $\mathbf{1 9 9 3}$ & 7.06 & 130 & 5.59 & 125 & 22,567 & 131 & 0.0549 & 131 \\
\hline $\mathbf{1 9 9 4}$ & 6.65 & 147 & 6.01 & 149 & 24,019 & 151 & 0.1561 & 151 \\
\hline $\mathbf{1 9 9 5}$ & 6.72 & 227 & 5.69 & 224 & 24,536 & 228 & 0.1289 & 228 \\
\hline $\mathbf{1 9 9 6}$ & 6.91 & 237 & 5.95 & 237 & 25,974 & 238 & 0.1411 & 238 \\
\hline $\mathbf{1 9 9 7}$ & 6.90 & 247 & 5.74 & 244 & 25,727 & 247 & 0.0869 & 247 \\
\hline $\mathbf{1 9 9 8}$ & 6.88 & 273 & 5.82 & 269 & 27,542 & 273 & 0.1042 & 273 \\
\hline $\mathbf{1 9 9 9}$ & 6.90 & 308 & 5.73 & 302 & 27,689 & 308 & 0.0998 & 308 \\
\hline $\mathbf{2 0 0 0}$ & 7.01 & 309 & 6.35 & 304 & 29,128 & 310 & 0.0327 & 310 \\
\hline $\mathbf{2 0 0 1}$ & 6.79 & 335 & 6.11 & 331 & 25,806 & 336 & 0.0811 & 336 \\
\hline $\mathbf{2 0 0 2}$ & 6.66 & 349 & 5.70 & 345 & 25,510 & 350 & 0.0968 & 350 \\
\hline $\mathbf{2 0 0 3}$ & 6.90 & 541 & 5.64 & 536 & 25,741 & 544 & 0.1276 & 544 \\
\hline $\mathbf{2 0 0 4}$ & 6.59 & 554 & 5.58 & 543 & 24,685 & 556 & 0.1591 & 556 \\
\hline $\begin{array}{l}\text { mean } \\
\mathbf{9 2 - 0 4}\end{array}$ & 6.84 & 3,752 & 5.80 & 3,704 & 25,707 & 3,767 & 0.1111 & 3,767 \\
\hline $\begin{array}{l}\text { mean } \\
\mathbf{9 2 - 9 7}\end{array}$ & 6.90 & 1,083 & 5.82 & 1,074 & 24,516 & 1,090 & 0.1151 & 1,090 \\
\hline $\begin{array}{l}\text { mean } \\
\mathbf{9 8 - 0 4}\end{array}$ & 6.81 & 2,669 & 5.79 & 2,630 & 26,398 & 2,677 & 0.1089 & 2,677 \\
\hline
\end{tabular}


Table A-7

\section{Turkish Foreigners, West Germany 1984-2004}

\begin{tabular}{|c|c|c|c|c|c|c|c|c|}
\hline Year & LS & n LS & $\begin{array}{c}\text { Sat } \\
\text { hhinc }\end{array}$ & $\begin{array}{c}n \\
\text { sat_inc }\end{array}$ & $\begin{array}{c}\text { HH } \\
\text { Income }\end{array}$ & $n$ inc & $\begin{array}{c}\text { unemp } \\
\text { rate }\end{array}$ & $\begin{array}{c}\text { n unemp. } \\
\text { rate }\end{array}$ \\
\hline 1984 & 6.91 & 981 & 5.87 & 979 & 23,959 & 989 & 0.1042 & 989 \\
\hline 1985 & 6.71 & 828 & 5.71 & 825 & 22,635 & 832 & 0.1537 & 832 \\
\hline 1986 & 6.93 & 831 & 6.01 & 826 & 24,000 & 834 & 0.1359 & 834 \\
\hline 1987 & 6.84 & 844 & 6.03 & 838 & 25,812 & 847 & 0.1441 & 847 \\
\hline 1988 & 6.90 & 833 & 6.04 & 827 & 25,990 & 836 & 0.1328 & 836 \\
\hline 1989 & 6.77 & 853 & 5.81 & 847 & 25,043 & 855 & 0.0931 & 855 \\
\hline 1990 & 6.93 & 836 & 5.81 & 834 & 24,960 & 839 & 0.1169 & 839 \\
\hline 1991 & 7.00 & 859 & 6.13 & 851 & 28,067 & 863 & 0.0933 & 863 \\
\hline 1992 & 6.94 & 860 & 5.80 & 854 & 27,710 & 867 & 0.1296 & 867 \\
\hline 1993 & 6.73 & 844 & 5.62 & 832 & 25,365 & 850 & 0.1508 & 850 \\
\hline 1994 & 6.68 & 794 & 5.13 & 783 & 24,562 & 798 & 0.1755 & 798 \\
\hline 1995 & 6.76 & 785 & 5.39 & 782 & 22,404 & 790 & 0.2612 & 790 \\
\hline 1996 & 6.75 & 742 & 5.39 & 737 & 22,015 & 745 & 0.2172 & 745 \\
\hline 1997 & 6.52 & 700 & 5.15 & 695 & 22,418 & 704 & 0.1869 & 704 \\
\hline 1998 & 6.60 & 651 & 5.17 & 649 & 23,475 & 654 & 0.2022 & 654 \\
\hline 1999 & 6.65 & 613 & 5.14 & 608 & 23,016 & 617 & 0.2188 & 617 \\
\hline 2000 & 6.51 & 561 & 5.26 & 562 & 25,370 & 566 & 0.1524 & 566 \\
\hline 2001 & 6.45 & 551 & 5.06 & 548 & 23,976 & 552 & 0.2760 & 552 \\
\hline 2002 & 6.46 & 501 & 5.29 & 497 & 22,967 & 503 & 0.2294 & 503 \\
\hline 2003 & 6.36 & 544 & 5.27 & 539 & 25,308 & 546 & 0.2369 & 546 \\
\hline 2004 & 6.30 & 509 & 5.12 & 504 & 25,090 & 510 & 0.3259 & 510 \\
\hline $\begin{array}{l}\text { mean } \\
\text { 84-04 } \\
\end{array}$ & 6.70 & 15,520 & 5.50 & 15,417 & 24,485 & 15,597 & 0.1789 & 15,597 \\
\hline $\begin{array}{l}\text { mean } \\
84-90 \\
\end{array}$ & 6.86 & 6,006 & 5.89 & 5,976 & 24,706 & 6,032 & 0.1245 & 6,032 \\
\hline $\begin{array}{l}\text { mean } \\
91-04 \\
\end{array}$ & 6.65 & 9,514 & 5.38 & 9,441 & 24,412 & 9,565 & 0.1968 & 9,565 \\
\hline $\begin{array}{l}\text { mean } \\
91-97 \\
\end{array}$ & 6.77 & 5,584 & 5.51 & 5,534 & 24,678 & 5,617 & 0.1730 & 5,617 \\
\hline $\begin{array}{l}\text { mean } \\
98-04\end{array}$ & 6.50 & 3,930 & 5.18 & 3,907 & 24,041 & 3,948 & 0.2301 & 3,948 \\
\hline
\end{tabular}


Table A-8

Germans, East Germany 1991-2004

\begin{tabular}{|l|c|r|r|r|r|r|r|r|}
\hline Year & LS & n LS & $\begin{array}{c}\text { Sat } \\
\text { hhinc }\end{array}$ & $\begin{array}{c}\mathbf{n} \\
\text { sat_inc }\end{array}$ & $\begin{array}{c}\text { HH } \\
\text { Income }\end{array}$ & n inc & $\begin{array}{c}\text { unemp } \\
\text { rate }\end{array}$ & $\begin{array}{c}\text { n unemp. } \\
\text { rate }\end{array}$ \\
\hline $\mathbf{1 9 9 1}$ & 6.05 & 3,896 & 4.78 & 3,905 & & & 0.1046 & 3,942 \\
\hline $\mathbf{1 9 9 2}$ & 6.13 & 3,760 & 4.91 & 3,745 & 17,649 & 3,791 & 0.1851 & 3,791 \\
\hline $\mathbf{1 9 9 3}$ & 6.21 & 3,620 & 5.36 & 3,550 & 19,907 & 3,644 & 0.1926 & 3,644 \\
\hline $\mathbf{1 9 9 4}$ & 6.26 & 3,577 & 5.46 & 3,510 & 21,808 & 3,592 & 0.2057 & 3,592 \\
\hline $\mathbf{1 9 9 5}$ & 6.39 & 3,502 & 5.56 & 3,430 & 22,277 & 3,515 & 0.1822 & 3,515 \\
\hline $\mathbf{1 9 9 6}$ & 6.39 & 3,501 & 5.63 & 3,430 & 22,741 & 3,504 & 0.1808 & 3,504 \\
\hline $\mathbf{1 9 9 7}$ & 6.32 & 3,452 & 5.42 & 3,363 & 23,331 & 3,458 & 0.1995 & 3,458 \\
\hline $\mathbf{1 9 9 8}$ & 6.48 & 3,666 & 5.52 & 3,565 & 23,072 & 3,676 & 0.2114 & 3,676 \\
\hline $\mathbf{1 9 9 9}$ & 6.52 & 3,609 & 5.56 & 3,516 & 23,910 & 3,613 & 0.1827 & 3,613 \\
\hline $\mathbf{2 0 0 0}$ & 6.44 & 3,563 & 5.74 & 3,477 & 24,197 & 3,572 & 0.1765 & 3,572 \\
\hline $\mathbf{2 0 0 1}$ & 6.46 & 3,423 & 5.75 & 3,373 & 23,686 & 3,429 & 0.1915 & 3,429 \\
\hline $\mathbf{2 0 0 2}$ & 6.26 & 3,301 & 5.48 & 3,238 & 23,771 & 3,307 & 0.1923 & 3,307 \\
\hline $\mathbf{2 0 0 3}$ & 6.34 & 4,837 & 5.42 & 4,756 & 24,208 & 4,842 & 0.2187 & 4,842 \\
\hline $\mathbf{2 0 0 4}$ & 6.13 & 4,725 & 5.21 & 4,628 & 23,660 & 4,739 & 0.1949 & 4,739 \\
\hline $\begin{array}{l}\text { mean } \\
\mathbf{9 1 - 0 4}\end{array}$ & 6.31 & 52,432 & 5.39 & 51,486 & 22,505 & 48,682 & 0.1872 & 52,624 \\
\hline $\begin{array}{l}\text { mean } \\
\mathbf{9 1 - 9 7}\end{array}$ & 6.25 & 25,308 & 5.30 & 24,933 & 21,297 & 21,504 & 0.1787 & 25,446 \\
\hline $\begin{array}{l}\text { mean } \\
\mathbf{9 8 - 0 4}\end{array}$ & 6.37 & 27,124 & 5.49 & 26,553 & 23,763 & 27,178 & 0.1974 & 27,178 \\
\hline
\end{tabular}

a. Not available. 
Table A-9

Migrants from West to East Germany, East Germany 1993-2004

\begin{tabular}{|l|c|r|r|r|r|r|r|r|}
\hline Year & \multicolumn{1}{c|}{ LS } & \multicolumn{1}{c|}{ n LS } & $\begin{array}{c}\text { Sat } \\
\text { hhinc }\end{array}$ & $\begin{array}{c}\text { n } \\
\text { sat_inc }\end{array}$ & $\begin{array}{c}\text { HH } \\
\text { Income }\end{array}$ & \multicolumn{1}{c|}{ n inc } & \multicolumn{1}{c|}{$\begin{array}{c}\text { unemp } \\
\text { rate }\end{array}$} & $\begin{array}{c}\text { n unemp. } \\
\text { rate }\end{array}$ \\
\hline $\mathbf{1 9 9 3}$ & 6.87 & 16 & 7.30 & 16 & 29,184 & 16 & 0.0655 & 16 \\
\hline $\mathbf{1 9 9 4}$ & 6.27 & 20 & 7.54 & 20 & 23,250 & 20 & 0.0512 & 20 \\
\hline $\mathbf{1 9 9 5}$ & 6.69 & 26 & 6.20 & 26 & 26,602 & 26 & 0.1594 & 26 \\
\hline $\mathbf{1 9 9 6}$ & 5.54 & 33 & 4.49 & 32 & 25,155 & 33 & 0.1765 & 33 \\
\hline $\mathbf{1 9 9 7}$ & 5.98 & 37 & 4.81 & 36 & 25,248 & 37 & 0.0744 & 37 \\
\hline $\mathbf{1 9 9 8}$ & 6.24 & 38 & 4.57 & 37 & 27,370 & 38 & 0.2571 & 38 \\
\hline $\mathbf{1 9 9 9}$ & 6.47 & 38 & 5.17 & 37 & 29,247 & 38 & 0.1343 & 38 \\
\hline $\mathbf{2 0 0 0}$ & 6.34 & 36 & 5.39 & 36 & 25,936 & 36 & 0.1646 & 36 \\
\hline $\mathbf{2 0 0 1}$ & 6.53 & 46 & 6.12 & 46 & 27,550 & 47 & 0.0124 & 47 \\
\hline $\mathbf{2 0 0 2}$ & 5.94 & 53 & 5.38 & 53 & 27,989 & 53 & 0.1678 & 53 \\
\hline $\mathbf{2 0 0 3}$ & 6.49 & 91 & 5.53 & 91 & 25,943 & 92 & 0.2607 & 92 \\
\hline $\mathbf{2 0 0 4}$ & 5.96 & 96 & 5.59 & 92 & 29,778 & 96 & 0.1024 & 96 \\
\hline $\begin{array}{l}\text { mean } \\
\mathbf{9 3 - 0 4}\end{array}$ & 6.23 & 530 & 5.54 & 522 & 27,068 & 532 & 0.1452 & 532 \\
\hline $\begin{array}{l}\text { mean } \\
\mathbf{9 3 - 9 7}\end{array}$ & 6.17 & 132 & 5.79 & 130 & 25,535 & 132 & 0.1119 & 132 \\
\hline $\begin{array}{l}\text { mean } \\
\mathbf{9 8 - 0 4}\end{array}$ & 6.26 & 398 & 5.41 & 392 & 27,850 & 400 & 0.1622 & 400 \\
\hline
\end{tabular}


Table A-10

Foreigners, East Germany 1991-2004

\begin{tabular}{|c|c|c|c|c|c|c|c|c|}
\hline Year & LS & n LS & $\begin{array}{c}\text { Sat } \\
\text { hhinc }\end{array}$ & $\begin{array}{c}n \\
\text { sat_inc }\end{array}$ & $\begin{array}{c}\text { HH } \\
\text { Income }\end{array}$ & $n$ inc & $\begin{array}{c}\text { unemp } \\
\text { rate }\end{array}$ & $\begin{array}{c}\text { n unemp. } \\
\text { rate }\end{array}$ \\
\hline 1991 & 4.79 & 14 & 3.07 & 14 & a & & 0.3158 & 14 \\
\hline 1992 & 4.97 & 10 & 3.57 & 10 & 23,837 & 10 & 0.2059 & 10 \\
\hline 1993 & 4.10 & 7 & 3.76 & 7 & 30,094 & 7 & 0.8617 & 7 \\
\hline 1994 & 5.24 & 11 & 3.30 & 11 & 25,465 & 11 & 0.4461 & 11 \\
\hline 1995 & 5.35 & 17 & 4.21 & 15 & 25,364 & 17 & 0.0656 & 17 \\
\hline 1996 & 5.17 & 10 & 5.46 & 10 & 28,500 & 10 & 0.6421 & 10 \\
\hline 1997 & 4.27 & 10 & 4.03 & 9 & 25,973 & 10 & 0.3620 & 10 \\
\hline 1998 & 5.68 & 10 & 4.01 & 10 & 22,715 & 10 & 0.3633 & 10 \\
\hline 1999 & 5.44 & 9 & 3.97 & 9 & 24,545 & 9 & 0.8187 & 9 \\
\hline 2000 & 6.19 & 9 & 5.42 & 9 & 26,122 & 9 & 0.6172 & 9 \\
\hline 2001 & 4.79 & 7 & 4.50 & 7 & 35,173 & 7 & 0.8214 & 7 \\
\hline 2002 & 6.34 & 8 & 6.43 & 8 & 20,854 & 8 & 0.2825 & 8 \\
\hline 2003 & 5.64 & 12 & 4.71 & 12 & 19,516 & 12 & 0.0727 & 12 \\
\hline 2004 & 6.33 & 12 & 5.13 & 12 & 24,536 & 12 & 0.7123 & 12 \\
\hline $\begin{array}{l}\text { mean } \\
91-04\end{array}$ & 5.29 & 146 & 4.31 & 143 & 25,079 & 132 & 0.4242 & 146 \\
\hline $\begin{array}{l}\text { mean } \\
91-97\end{array}$ & 4.89 & 79 & 3.85 & 76 & 26,216 & 65 & 0.3691 & 79 \\
\hline $\begin{array}{l}\text { mean } \\
98-04 \\
\end{array}$ & 5.77 & 67 & 4.84 & 67 & 23,961 & 67 & 0.4898 & 67 \\
\hline
\end{tabular}

a. Not available. 


\section{Appendix B}

Life Satisfaction on Specified Variable(s)

Cross Sectional Regression for Population Subgroups (n=7), 1991-2004

\begin{tabular}{|c|r|r|r|r|r|r|r|r|}
\hline & \multicolumn{2}{|c|}{ Sat income } & \multicolumn{2}{c|}{ HH Income x 10 } & \multicolumn{2}{c|}{ Unemp. rate } & & \\
\cline { 2 - 8 } Reg. & Coeff. & t-stat & Coeff. & t-stat & Coeff. & t-stat & Adj. $\mathbf{R}^{2}$ & Prob>F \\
\hline 1 & 0.830 & 6.09 & & & & & 0.858 & 0.002 \\
\hline 2 & & & 13.02 & 1.13 & & & 0.045 & 0.309 \\
\hline 3 & & & & & -0.049 & -5.92 & 0.850 & 0.002 \\
\hline 4 & & & 0.191 & 0.03 & -0.049 & -4.64 & 0.813 & 0.016 \\
\hline
\end{tabular}

a. For regressions with household income, 1992-2004. 


\section{Appendix C}

Life Satisfaction on Specified Variable(s)

Time Series Regressions by Population Subgroup and Specified Period

\begin{tabular}{|c|c|c|c|c|c|c|c|c|c|c|}
\hline \multirow{2}{*}{$\begin{array}{l}\text { Pop. } \\
\text { group }\end{array}$} & \multirow[b]{2}{*}{ Period } & \multirow[b]{2}{*}{$\mathbf{n}$} & \multicolumn{2}{|c|}{ Sat income } & \multicolumn{2}{|c|}{ HH Income $x 10^{-5}$} & \multicolumn{2}{|c|}{ Unemp. rate } & \multirow{2}{*}{$\begin{array}{r}\text { Adj. } \\
\mathbf{R}^{2}\end{array}$} & \multirow{2}{*}{$\begin{array}{r}\text { Prob } \\
>\mathbf{F}\end{array}$} \\
\hline & & & Coeff. & t-stat & Coeff. & t-stat & Coeff. & t-stat & & \\
\hline \multicolumn{11}{|c|}{ 1. Germany } \\
\hline & $91-04$ & 14 & 0.692 & 4.68 & & & & & 0.617 & 0.001 \\
\hline & $92-04$ & 13 & & & -5.37 & -1.75 & & & 0.147 & 0.108 \\
\hline & 91-04 & 14 & & & & & -4.639 & -3.69 & 0.492 & 0.003 \\
\hline & $92-04$ & 13 & & & -5.02 & -2.10 & -4.724 & -2.86 & 0.484 & 0.015 \\
\hline \multicolumn{11}{|c|}{ 2. West Germany (WG) } \\
\hline & $91-04$ & 14 & 0.712 & 6.54 & & & & & 0.763 & 0.000 \\
\hline & 91-04 & 14 & & & -3.19 & -0.64 & & & -0.048 & 0.535 \\
\hline & $91-04$ & 14 & & & & & -6.980 & -5.21 & 0.668 & 0.000 \\
\hline & $91-04$ & 14 & & & -5.92 & -2.48 & -7.469 & -6.57 & 0.768 & 0.000 \\
\hline \multicolumn{11}{|c|}{ 3. West Germany (WG) } \\
\hline & $84-04$ & 21 & 0.685 & 3.99 & & & & & 0.427 & 0.001 \\
\hline & 84-04 & 21 & & & -6.69 & -3.00 & & & 0.286 & 0.007 \\
\hline & $84-04$ & 21 & & & & & -6.997 & -5.26 & 0.571 & 0.000 \\
\hline & $84-04$ & 21 & & & -4.54 & -3.02 & -6.036 & -5.21 & 0.699 & 0.000 \\
\hline \multicolumn{11}{|c|}{ 4. East Germany (EG) } \\
\hline & $91-04$ & 14 & 0.447 & 6.27 & & & & & 0.747 & 0.000 \\
\hline & $92-04$ & 13 & & & 4.06 & 2.49 & & & 0.302 & 0.030 \\
\hline & 91-04 & 14 & & & & & 2.519 & 1.79 & 0.146 & 0.098 \\
\hline & $92-04$ & 13 & & & 4.27 & 2.50 & -1.725 & -0.64 & 0.263 & 0.088 \\
\hline \multicolumn{11}{|c|}{ 5. Germans WG } \\
\hline & $91-04$ & 14 & 0.721 & 6.73 & & & & & 0.773 & 0.000 \\
\hline & 91-04 & 14 & & & -4.50 & -0.94 & & & -0.009 & 0.365 \\
\hline & $91-04$ & 14 & & & & & -7.442 & -5.48 & 0.691 & 0.000 \\
\hline & 91-04 & 14 & & & -4.75 & -2.00 & -7.483 & -6.16 & 0.753 & 0.000 \\
\hline \multicolumn{11}{|c|}{ 6. Germans WG } \\
\hline & $84-04$ & 21 & 0.651 & 3.49 & & & & & 0.359 & 0.002 \\
\hline & $84-04$ & 21 & & & -6.69 & -3.20 & & & 0.316 & 0.005 \\
\hline & 84-04 & 21 & & & & & -7.645 & -5.35 & 0.580 & 0.000 \\
\hline & $84-04$ & 21 & & & -4.34 & -2.99 & -6.441 & -5.09 & 0.704 & 0.000 \\
\hline \multicolumn{11}{|c|}{ 7. European foreigners WG } \\
\hline & 84-04 & 21 & 0.465 & 3.65 & & & & & 0.381 & 0.002 \\
\hline & 84-04 & 21 & & & -1.66 & -0.81 & & & -0.018 & 0.430 \\
\hline & $84-04$ & 21 & & & & & -2.123 & -1.81 & 0.103 & 0.086 \\
\hline & $84-04$ & 21 & & & -2.24 & -1.15 & -2.327 & -1.98 & 0.118 & 0.125 \\
\hline
\end{tabular}




\section{Appendix C (continued)}

\begin{tabular}{|c|c|c|c|c|c|c|c|c|c|c|}
\hline \multirow{2}{*}{$\begin{array}{l}\text { Pop. } \\
\text { group }\end{array}$} & \multirow[b]{2}{*}{ Period } & \multirow[b]{2}{*}{$\mathbf{n}$} & \multicolumn{2}{|c|}{ Sat income } & \multicolumn{2}{|c|}{ HH Income $x 10^{-5}$} & \multicolumn{2}{|c|}{ Unemp. rate } & \multirow{2}{*}{$\begin{array}{r}\text { Adj. } \\
\text { R2 } \\
\end{array}$} & \multirow{2}{*}{$\begin{array}{r}\text { Prob } \\
>F\end{array}$} \\
\hline & & & Coeff. & t-stat & Coeff. & t-stat & Coeff. & t-stat & & \\
\hline \multicolumn{11}{|c|}{ 8. European foreigners WG } \\
\hline & 91-04 & 14 & 0.519 & 3.45 & & & & & 0.456 & 0.005 \\
\hline & 91-04 & 14 & & & 0.936 & 0.21 & & & -0.079 & 0.839 \\
\hline & $91-04$ & 14 & & & & & -2.539 & -1.63 & 0.119 & 0.199 \\
\hline & $91-04$ & 14 & & & -5.49 & -1.04 & -3.873 & -1.92 & 0.119 & 0.199 \\
\hline \multicolumn{11}{|c|}{ 10. Turkish foreigners WG } \\
\hline & 91-04 & 14 & 0.535 & 4.65 & & & & & 0.613 & 0.001 \\
\hline & $91-04$ & 14 & & & 4.1 & 1.42 & & & 0.073 & 0.181 \\
\hline & 91-04 & 14 & & & & & -2.388 & -3.65 & 0.486 & 0.003 \\
\hline & 91-04 & 14 & & & -0.359 & -0.13 & -2.449 & -2.98 & 0.440 & 0.016 \\
\hline \multicolumn{11}{|c|}{ 11. Mig E-W } \\
\hline & $92-04$ & 13 & 0.296 & 1.10 & & & & & 0.017 & 0.295 \\
\hline & $92-04$ & 13 & & & -2.95 & -0.98 & & & -0.004 & 0.349 \\
\hline & $92-04$ & 13 & & & & & -2.547 & -1.61 & 0.117 & 0.136 \\
\hline & $92-04$ & 13 & & & -4.7 & -1.73 & -3.325 & -2.18 & 0.252 & 0.094 \\
\hline \multicolumn{11}{|c|}{ 12. Germans EG } \\
\hline & 91-04 & 14 & 0.451 & 6.31 & & & & & 0.749 & 0.000 \\
\hline & $92-04$ & 13 & & & 3.92 & 2.36 & & & 0.276 & 0.038 \\
\hline & 91-04 & 14 & & & & & 2.296 & 1.61 & 0.109 & 0.133 \\
\hline & $92-04$ & 13 & & & 4.14 & 2.42 & -2.041 & -0.79 & 0.250 & 0.095 \\
\hline \multicolumn{11}{|c|}{ 13. Foreigners EG } \\
\hline & 91-04 & 14 & 0.488 & 3.03 & & & & & 0.386 & 0.011 \\
\hline & $92-04$ & 13 & & & -9.95 & -2.25 & & & 0.254 & 0.046 \\
\hline & & & & & & & -0.356 & -0.49 & -0.062 & 0.633 \\
\hline & $92-04$ & 13 & & & -14.35 & -2.42 & 0.926 & 1.10 & 0.267 & 0.085 \\
\hline \multicolumn{11}{|c|}{ 14. Mig W-E } \\
\hline & $93-04$ & 12 & 0.234 & 2.44 & & & & & 0.311 & 0.035 \\
\hline & $93-04$ & 12 & & & 5.09 & 0.88 & & & -0.022 & 0.402 \\
\hline & 93-04 & 12 & & & & & -0.774 & -0.52 & -0.071 & 0.615 \\
\hline & $93-04$ & 12 & & & 4.98 & 0.82 & -0.726 & -0.48 & -0.107 & 0.641 \\
\hline
\end{tabular}

